\title{
Commonwealth Regulation of Campaign Finance - Public Funding, Disclosure and Expenditure Limits
}

Deborah Z Cass and Sonia Burrows

Deborah Z Cass and Sonia Burrows, 'Commonwealth Regulation of Campaign

Finance - Public Funding, Disclosure and Expenditure Limits' (2000) 22(4)

Sydney Law Review 477, 477-526 <http://www.austlii.edu.au/au/journals/ SydLawRw/2000/23.pdf>.

Reproduced with the permission of the Sydney Law Review.

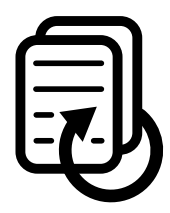





\title{
Commonwealth Regulation of Campaign Finance - Public Funding, Disclosure and Expenditure
} Limits

\author{
DEBORAH Z CASS $^{*}$ AND SONIA BURROWS ${ }^{\dagger}$
}

\section{Introduction ${ }^{1}$}

\section{A. Outline of Article}

The regulation of the relationship between money and politics is a topic of perennial significance to anyone interested in the democratic process. As a subset of a discussion about public trust and public accountability it has a long pedigree in Australia. ${ }^{2}$ State specific and comparative collections of essays on the topic have been produced ${ }^{3}$ and both the legal and political science communities have taken an interest in it. ${ }^{4}$ In the United States campaign finance has particular cachet because it is dealt with under the general rubric of First Amendment free speech jurisprudence. ${ }^{5}$ Moreover interest is reignited periodically ${ }^{6}$ when the press discovers the existence of new devices for encouraging gift-giving such as a coffee with the President, or renting a White House suite for a night.

- London School of Economics and Political Science Law Department. LLB (Melb), LLM (Harvard). We would like to thank Peta Stevenson for her research assistance with this project, and the Reshaping Australia's Institutions project at the Research School of Social Sciences, Australian National University.

† LLB (Hons) student, Australian National University.

1 The law is stated as at August 2000.

2 For example, Paul Finn, 'Public Trust and Public Accountability' (1994) 3 GLR 224.

3 For example, Herbert Alexander \& Shiratori Rei (eds), Comparative Political Finance Among the Democracies (1994); Herbert E Alexander, Financing Politics: Money Elections and Political Reform (4 ${ }^{\text {th }}$ ed, 1992); Keith Ewing, The Funding of Political Parties in Britain (1986).

4 For example, Alexander, Financing Politics, above n3. In Australian political science literature, see for example, Colin Hughes, 'Australia' (1963) The Journal of Politics 646; Ernest Chaples, 'Developments in Australian Election Finance' in Alexander \& Rei, above $n 3$.

5 See, for example, Cass Sunstein, Democracy and the Problem of Free Speech (1993). The foundational US case around which discussion revolves is Buckley v Valeo, 424 US 1, $46 \mathrm{~L}$. Ed. 2d 659, $96 \mathrm{~S}$. Ct, 612 (1976) which distinguished between expenditure limits and contribution limits, finding the former were unconstitutional whereas the latter, subject to conditions, were not.

6 A recent excellent collection of views on the topic can be found in 50 Stan LR (1998). 
Australian legal literature on campaign finance is relatively sparse ${ }^{7}$ as, it appears, is political comment. ${ }^{8}$ This is somewhat surprising, given that recent inquiries into government corruption in Australia in the last two decades refer to the topic as being unavoidable in any inquiries into, and attempts at, protecting the integrity of government. ${ }^{9}$

This article is a brief survey, from Federation to the present day, of some key aspects of campaign finance regulation related to public funding, disclosure and expenditure limits. It suggests that three features characterise the Australian regulatory approach to these issues: a steady increase in regulatory control; an increasingly complex regulatory environment which seeks to balance public and private interests; and an acceptance of the constitutional feasibility of expenditure limits. Specifically, we will argue here, first, that although the history of regulation in Australia has experienced some dormant periods, and even a period of complete de-regulation, the overall trend has been towards increasing regulatory control. Second, current regulatory techniques extend to include an emphasis upon the regulation of entities associated with political parties and candidates, rather than simply the political participants themselves. That is, at present some regulation is directed towards placing tighter controls on the conduct of traditional participants such as political parties, and some is directed toward enhancing the ability of private donors to contribute to the political process, while simultaneously controlling their behaviour. A further concern is control over public funding. The complex relationship between providing public support for elections, encouraging private participation in public political activity, regulating that activity and public controls on political party conduct is a constant theme of the current regulatory context. Third, we will argue that an historical precedent exists for the introduction of campaign expenditure limits and that precedent is unlikely to have been affected by subsequent constitutional developments in relation to free speech.

It is not the aim of this article to explore the complex theoretical premises underlying regulation, which have been examined comprehensively elsewhere. ${ }^{10}$ Instead it is our aim to describe the history of a small, but significant selection of regulatory devices used in relation to campaign finance. Very briefly, however, it is clear that a number of principles inform the debate about campaign finance regulation. Principles of free speech; political equality; access to information; access to participation; trust in public officials; privacy; efficiency and individualism all vie for domination in the terrain of campaign finance reform.

7 See, for example, Keith Ewing, 'The Legal Regulation of Electoral Campaign Financing in Australia: A Preliminary Study' (1992) 22 UWALR 239; Finn, above n2.

8 Dr Carmen Lawrence recently stated that 'While there has been extensive debate about big money in politics in the US, there appears to be a conspiracy of silence among Australian politicians': quoted from her 17 August 2000 speech to the Sydney Institute, 'Renewing Democracy: Can Women Make a Difference'. Full transcript available online at http:// www.carmenlawrence.com/says/papers/sydneyinstitute.htm.

9 See, for example, Western Australia, Commission on Govemment, Report No. 2 Part 2, (1995).

10 The scholarship on the topic is voluminous. For a selection of recent approaches see 'Symposium: Law and the Political Process' 50 Stan LR (1998) and Corrado et al (eds), Campaign Finance Reform: A Sourcebook (1997). 
Moreover, as the vast scholarship on the topic indicates, a key problem here is striking the appropriate balance between these principles, all of which are legitimate in the abstract. So, for example, one writer referred to the Australian legislative framework as 'privileging ... political liberty over political equality'.11

One result of the clash of competing principles is the development of a broad range of regulatory devices. These include public funding of election campaigns, and the provision of tax credits or deductions for campaign donations. Governments may establish a regime of disclosure for donations to political participants, and/or of payments by political parties. Legislation may be aimed at achieving truth in political advertising. This article focuses on three of these devices - public funding and disclosure rules, and expenditure limits - as a means of exploring some of the ways in which the principles mentioned above operate in the legislative context.

\section{B. Nature of the Problem Addressed by Public Funding and Disclosure Rules}

The purpose of public funding and public disclosure rules is to avoid both the imputation and actuality of corruption. In general terms the underlying aim of the regulation of campaign finance is to preserve the integrity of the political process. By ensuring that the public is aware of the sums of money gifted to political parties, the public is able to judge the legitimacy of legislative proposals, and identify the avenues of influence that may affect politicians' judgments. This is the 'transparency furthers accountability' argument.

It is also said that transparency may discourage the parties from providing favours to donors for fear of reprisal from a well-informed public. Public funding of political parties reduces their need to rely on donations from external sources. Moreover, by reducing the need to rely on private donations a more level playing field for candidacy is constructed; candidates with limited private support can afford to run for political office against candidates who have access to either personal wealth or other sources of private support. This argument is concerned with equality of financial opportunity for potential political candidates.

It is clear that not all of the arguments for campaign finance regulation rely upon the supposition that interests that give money to political candidates and parties will necessarily demand their quid pro quo in terms of a policy outcome. For example the equality argument is not directly concerned with this possibility.

11 Ewing, above $\mathrm{n} 7$. The attempt to achieve a 'balance' of regulation assumes that the poles themselves are secure. The appearance of the principle of 'free speech' for and against regulation should immediately alert the reader to the contestable nature of any assumed opposition between these principles. One concern of this area is to recognise the way campaign finance regulation can be both rejected and justified on the basis of different conceptions of free speech; see: Turner Broadcasting System v FCC, 117 St. Ct. 1174 (1997). 
In fact, empirical research on whether campaign donations influence policy decisions is equivocal. ${ }^{12}$ However counter-intuitive it may seem, some commentators believe that money does not and cannot directly cause changes in policy outcomes. Professor Rolf Gerritson, appearing before the Australian Senate's Finance and Public Administration Legislation Committee in 1998, expressed this view:

From my observations, it appears that there is no correlation between public policy outcomes and the pattern of donations; that corporations tend to donate to political parties, if you like, to reward a policy stance rather than to induce one. ${ }^{13}$

One of the interesting phenomena of campaign financing, and a reason why the predictability of the money/politics link is problematic, is the existence of anecdotal evidence that corporate interests give donations to more than one of the major parties, albeit in different amounts. So, for example, in the 1992 Australian election, one major Australian company, Amcor, donated $\$ 30000$ to the Australian Labor Party and $\$ 100000$ to the Coalition parties. ${ }^{14}$ If the political contest is conceived of as occurring only between political parties, then this practice muddies the conclusions that may be drawn from gift-giving. It produces a kind of stalemate in which a party cannot, without criticism, claim that a donation 'bought ... decisions' from the other side of politics without tarring itself with the same brush. ${ }^{15}$ However if the political contest is conceptualised as including interests other than political parties, such as community groups, business and union organizations, and indeed the public at large, then Amcor's actions, even if equal as between political parties, have bought an advantage over all these other political competitors, all of whom are legitimate actors in the political process.

Occasionally the claim is made that particular donations or monetary benefits have led to particular legislative outcomes in favour of the contributor. For example, it was claimed in the Australian Parliament in 1998 that the Liberal Party was lent $\$ 10$ million by National Australia Bank for its 1996 election campaign, on the condition that, if elected, as government it would open the superannuation industry up to the banks - a legislative outcome which subsequently came about. ${ }^{16}$

The question of the influence of campaign contributions upon political outcomes is really unanswerable. Given the range of variables which influence

12 Although the Sydney Morning Herald recently quoted a Business Week/Harris Poll, surveying 400 senior executives of large public corporations in the United States and exploring their reasons for donating to political parties. They discovered that 'a worrying $41 \%$ said that at least part of their reason ... was the hope of receiving "preferential consideration on regulations or legislation benefiting our business"': Michelle Grattan, 'Money and the Politics of Schmooze', The Sydney Morning Herald (25 August 2000).

13 Australia, Senate, Finance and Public Administration Legislation Committee, Hansard, Electoral and Referendum Amendment Bill (No. 2) 1998, Tuesday 16 June 1988, Canberra at 21.

14 Australia, House of Representatives, Parliamentary Debates (Hansard), 3 June 1998 at 4674.

15 Id at $4675-4676$.

16 Bob McMullan, Australia, House of Representatives, Parliamentary Debates (Hansard), 23 March 1998 at 1346. 
political decision-making, it would be impossible to construct an experiment to test the hypothesis that money corrupts politics. To this extent then, the question of proof of influence is irrelevant.

However what is not irrelevant is the perception that the possibility that money can influence politics is enough to cause a different sort of problem for democracy, and that is the problem of a general disillusionment with the political process. It is generally accepted that increasing numbers of people are losing faith in the political process, in politicians, and ultimately in the promise that democracy can ensure a fair, equal and participatory method of governance. In a submission in 1998 to a governmental committee on electoral reform one Australian Senator described a 'crisis of public confidence concerning political parties and politicians' referring to the 'deep levels of cynicism and disillusionment within the electorate towards their elected representatives' which was reflected in opinion polling findings that less than 10 per cent of Australians believed that their politicians held high standards of ethics and honesty. ${ }^{17}$ In relation to this form of democracy fatigue, the possibility of politics even being tainted by the influence of campaign finance is a real problem. In the words of one commentator - 'I do think the public standing of politicians is important, and I think it is being damaged by this kind of covert behaviour.'18

Some anecdotal evidence exists to suggest that political parties are exploiting methods that disguise the receipt of political money and its source. Devices of this sort inevitably raise questions as to the reasons for keeping sources hidden, with one answer being that it allows the protection of sources of funds in the event that the party subsequently provides them with a political benefit or advantage. One method currently widely used to disguise donation sources has been the creation of trusts and foundations through which donations are channelled. For example claims have been made in the Australian Parliament that one of the major parties received income of $\$ 7.2$ million laundered through a trust. ${ }^{19}$ This device reputedly allowed donations to the trust, which then gave the money to the political party. Since the trust was not subject to the appropriate regulatory legislation, the original sources of the contributions were not disclosed. ${ }^{20}$

Other techniques do not disguise donation sources, but are simply created to increase the sums of money available to compete successfully in the political market. Included amongst the new money-raising techniques of campaign financing are: the siphoning off of rents from investments; ${ }^{21}$ the leasing out at high

17 Senate, Finance and Public Administration Legislation Committee, Submissions, Reference: Electoral and Referendum Amendment Bill (No. 2) 1998 at 38. Submission of Senator Andrew Murray (Australian Democrats).

18 Professor Rolf Gerritson, above n13.

19 It was said that the Liberal Party received \$7.2 million through the Free Enterprise Foundation: - Australia, House of Representatives, Parliamentary Debates (Hansard), 9 March 1995 at 1950.

20 Bob McMullan, Australia, House of Representatives, Parliamentary Debates (Hansard), 23 March 1998 at 1346.

21 The Labor Party was reputed to have received \$1.6 million from rents from John Curtin House Pty. Ltd without disclosing: Australia, House of Representatives, Parliamentary Debates (Hansard), 9 March 1995 at 1950. 
rates of property to government departments; ${ }^{22}$ the giving of loans on favourable terms, which are themselves not disclosed ${ }^{23}$ or the conversion of loans into gifts, by non-enforcement. ${ }^{24}$ Whilst secondary to the problem of the influence of money on policy formulation, they are nevertheless important given the increasing pressure upon parties to seek illicit donations in bids to fund a successful campaign, donations which may be conditional upon political favours.

For regulators the problem is further compounded by the fact that, like tax avoidance, this area is always a case of 'catch-up politics'. ${ }^{25}$ As soon as one loophole is closed, another will open. One recent development has been the replacement by a political party of a long-standing campaign fund-raising body with a new entity, thus avoiding the reach of the Australian Electoral Commission (AEC) and the legislative requirements of disclosure. In one case the new entity shared common trustees, postal address, and accountancy support with the preexisting foundation, but was reluctant to provide information regarding its status to the Commission, thus thwarting the ability of the regulatory body to monitor the disclosure requirement. ${ }^{26}$

Whether one accepts in theory the need for campaign finance regulation or not, there are also strong practical reasons suggesting that political players ought to be more accountable. One such reason concerns the imbalance between regulation of private and public organisations apparently committed to the public interest. The argument is that organisations such as political parties, although private in nature, serve a major public interest, namely the election of representatives to represent the interests of the public in determining major political decisions, and hence

22 The claim was made in Parliament that the Labor Party had leased out at "exorbitant rent its property to Commonwealth Departments, including the Auditor General': id at 1953.

23 See, for example, John Faulkner, Australia, Senate, Parliamentary Debates (Hansard), 3 March 1998 at 200; Bob McMullan, Australia, House of Representatives, Parliamentary Debates (Hansard), 23 March 1998 at 1346; John Faulkner, Australia, Senate, Parliamentary Debates (Hansard), 25 June 1998 at 4174 . See also Lenore Taylor, 'Liberals receive a $\$ 4.6 \mathrm{~m}$ secret loan', Australian Financial Review (3 February 1998) at 3; Minister won't detail Greenfields Foundation \$4.6 million loan to Libs', Canberra Times (9 March 1998) at 5.

24 See, for example, John Faulkner, Australia, Senate, Parliamentary Debates (Hansard), 28 May 1998 at 3357 ; id at 25 June 1998 at 4174.

25 John Faulkner, Australia, Senate, Parliamentary Debates (Hansard), 9 December 1999 at 11565; Lenore Taylor, ' $\$ 4.6 \mathrm{~m}$ loan to the Liberals may spark electoral law change', Australian Financial Review (12 May 1998) at 3.

26 The claim was made over a series of months in the Australian Parliament by members of the opposition in relation to the establishment of the Greenfields Foundation. The new foundation, Greenfields, was established with similar trustees, postal address, and accounting support as the Free Enterprise Foundation, a foundation previously identified by the Commission as an associated entity under the Act and therefore required to disclose. The Greenfields Foundation however declined to provide details to the Commission that would have enabled the Commission to ascertain whether or not it was an associated entity. The Commission lacked the necessary investigatory powers to pursue the matter. See, for example, John Faulkner, Australia, Senate, Parliamentary Debates (Hansard), 3 March 1998 at 200; Bob McMullan, Australia, House of Representatives, Parliamentary Debates (Hansard), 23 March 1998 at 1346; John Faulkner, Australia, Senate, Parliamentary Debates (Hansard), 28 May 1998 at 3357 . See also Lenore Taylor, 'Secret foundation to look at taking donations', Australian Financial Review (5 February 1998) at 6. 
should be subject to public scrutiny and regulation, certainly no less so than are private organisations with public interests. 'Political parties are less regulated than corporations, trusts, partnerships, unions, employer organisations, welfare groups and tennis clubs. ${ }^{27}$ There is a disjunction between the very public role of the political party, and its very closed and private legal internal organisation. Their 'legal status is not appropriate to their actual role and their public status'. ${ }^{28}$ Therefore, so the argument goes, the techniques of corporate regulation could be transferred to the sphere of political party regulation. 29

Further, since 1983 political parties have been partially publicly funded and thus open accountability is required; they wield enormous power in public life; and by comparison with public listed companies and private limited companies their regulation is limited. ${ }^{30}$

Finally, in recent times concerns have also been raised about the use of public money to finance political advertising campaigns by incumbent governments just prior to the announcement of an election, thereby ameliorating the need to raise large sums of money and the accompanying disclosure rules. So, for example, in the lead up to the 1998 Australian election, the government was reported to have spent \$A28 million in an 'election advertising blitz' prior to the official announcement of polling ${ }^{31}$ on ads extolling the virtues of government reform, past and proposed, in areas as diverse as taxation and immunisation.

In sum, quite apart from the difficult theoretical issues concerning, for example, any contest between political equality and individualism, this section has briefly sketched the nature of the campaign finance problem and shown how regulation is said to be justified for reasons of preserving the integrity of the political process, confronting democracy fatigue, avoiding even the taint of untoward influence of money on political outcomes, and bringing public political bodies closer to regulation parity with private bodies involved in public life. The next part of the article surveys Commonwealth regulation of public funding and disclosure rules.

\section{Historical Background}

This part of the article will argue, first, that historical precedent exists for the current system of regulation. Campaign finance legislation in Australia had its genesis in the Commonwealth Electoral Act 1902 and was regularly reformed and updated over the ensuing years. The remarkable aspect of the original legislation of 1902 is that it contained most of the key elements of the current regulatory

27 Senate, Finance and Public Administration Legislation Committee, Submissions, Reference: Electoral and Referendum Amendment Bill (No. 2) 1998 at 48. Submission of Senator Andrew Murray (Australian Democrats).

28 Id at 50 .

29 Id at 48, 52, citing Allan Ware, Citizens, Parties and the State: A Reappraisal (1987) at 91.

30 Id at 51 .

31 Mike Seccombe, 'Election rumours sweep House', The Sydney Morning Herald (28 August, 1998). 
system. ${ }^{32}$ It contained disclosure and transparency rules; third-party regulation; it focused on the importance to campaign finance of advertising; and it contained simple regulation of the media. Historical continuity is therefore a significant characteristic of the current system.

However, the original legislation also contained one additional feature which is missing from the current system, namely, limits upon the amount of money political participants could spend in pursuit of their election. ${ }^{33}$ This section will make an argument that in view of the long historical pedigree of expenditure limits, and the absence of any criticism of expenditure limits specifically on the basis of Australian democracy, there is a case for arguing for their reinstatement. This is not an argument about justification; the many rationales for expenditure limits are beyond the limits of this article. Instead we will suggest, simply, that the (re)introduction of expenditure limits as a form of campaign finance regulation is not a new development in Australian politics; that they were a feature of the Australian constitutional landscape for 80 years; and accordingly that arguments based on the novelty, or incompatibility of such regulation with the practice of representative democracy, need to be treated with caution.

\section{A. The Original Legislation of 1902 - A Proposal for a System of Limited Campaign Finance}

What were the key elements of the first attempt at Commonwealth campaign finance regulation?

\section{(i) Expenditure Limits}

The first attempt at regulation of campaign finance in Australia contained expenditure limits. Part XIV of the Commonwealth Electoral Act 1902 was headed 'Limitation of Electoral Expenses' and section 169 provided that electoral expenses be limited to $£ 100$ for candidates ${ }^{34}$ for the House of Representatives and $£ 250$ for the Senate.

The early legislation also included some guidance as to the meaning of electoral expenses, although it is not entirely clear. Section 170 limited the range of matters which were authorised as electoral expenses to: printing, advertising, publishing, issuing and distributing of addresses by candidate and notices of meetings; general stationery expenses; hall and room hire and scrutineers. ${ }^{35}$ Section 171 was, however, more wide ranging. It provided that the term included

32 Commonwealth Electoral Act 1918 Part XX.

33 These limits were repealed by $\$ 4$ of the Commonwealth Electoral Amendment Act 1980.

34 It must be mentioned early on that at this point in Australia's history, political parties were not an important force - hence the emphasis upon candidates' expenses. The Labour Party, already strong in the colonies, particularly in NSW and Queensland (where it formed the world's first Labour Government for 7 days in 1899), became a Federal Party in 1901, but the rest of parliament consisted of various free trade and protection factions. The Farmers and Settler's Association created the Country Party in 1912, and it wasn't until 1944 that the Liberal Party was formed from a conglomerate of non-Labor members. Parties did not appear in electoral legislation until the Commonwealth Electoral Act 1918, a reflection of the changing reality of Australian politics.

35 Commonwealth Electoral Act 1902 s170. 
'all expenses incurred by or on behalf or in the interests of any candidate at or in connection with any election' subject to only two exceptions, the purchase of electoral rolls, and 'the personal and reasonable living and travelling expenses of the candidate'. ${ }^{36}$ Presumably the latter was read as subject to the former, to avoid any conflict between the two sections. In this event 'all expenses' would be authorised as long as they fell within the categories contained in section 170 and did not include electoral rolls or living/travel expenses.

It is possible that this combination of an expenditure limit and a limited definition of electoral expense may have led to a greater degree of financial equality of opportunity between candidates. With expenditure being capped there was no real advantage to greater access to resources because there was a limit upon what those resources could be spent on. Whether this translated in practice in a higher percentage of non-wealthy candidates running for office would be worth investigating.

\section{(ii) Disclosure and Transparency}

A simple form of the disclosure requirement also featured in the early legislation. Here disclosure took the form of a requirement for the submission of expenditure returns. It was necessary for all candidates, within eight weeks of the election, to return a signed statement to the Commonwealth Electoral Officer indicating all expenses paid and all disputed and unpaid expenses. ${ }^{37}$ Accountability and transparency were also anticipated. Receipts for electoral expenses were to be produced $^{38}$ and the returns were open for public inspection. ${ }^{39}$

\section{(iii) Third Parties - Individual and Collective Associated Entities}

Independent interest groups, other organisations and individuals were all required to furnish returns if they had spent any money or incurred any expense for a political participant. The legislation was drafted broadly to require returns from '[e]very trades union registered or unregistered, organisation, association, league, or body of persons which has, or person who has, in connection with any election expended any money or incurred any expense' on behalf or in the interests of any candidate or political party. ${ }^{40}$ Moreover the Chief Electoral Officer could require an officer of any such organisation to make an expenditure return or pay the appropriate penalty. ${ }^{41}$

Note that according to this aspect of the legislation third parties who spent on behalf of candidates (or political parties) were required to furnish returns, but not limited in the amount of money they spent. Also not mentioned in relation to expenditure limits or disclosure were political parties. This may have been because at the time the legislation was passed political parties were few and far between and relatively under-developed as fund-raising organisations for candidates.

\footnotetext{
36 Section 171.

37 Section 172(1).

38 Section $172(2)$.

39 Commonwealth Electoral Act 1905 s49, inserting s172(3) into the Principle Act.

40 Commonwealth Electoral Act 1911 s34, inserting s172A(1) into the Principle Act.

41 Id at inserting s172A(8) into the Principle Act.
} 


\section{(iv) Election Advertising}

The significance of election advertising was recognised by its specific inclusion in the list of matters that may have been the subject of expenditure by third parties. Election advertising was targeted for inclusion in third party returns. ${ }^{42}$ A penalty of $£ 50$ attached to any failure to comply with the section, and $£ 100$ or six months imprisonment for the wilful making of untrue statements in a return

\section{(v) Regulation of the Media}

Newspaper proprietors ${ }^{43}$ were also required to complete a return showing the amount of paid electoral matter inserted into the newspaper and setting out space it occupied, the amount paid for it, and names of the body or persons which authorised its insertion. Failure to do so carried a penalty of $£ 500$. 'Electoral matter' was defined broadly to include advertisements and any 'other matter intended or calculated to affect the result of the election'. ${ }^{44}$

In addition to these modern forms of regulation a number of the more serious traditionally recognised common law electoral offences were also enacted, including bribery and undue influence, ${ }^{45}$ although the category of illegal practices from which the latter were drawn was probably wider.

This brief description of the original legislation illustrates that there is a strong thread of historical continuity connecting early legislation with the current regulatory regime. This would indicate that the concerns of regulators have not dramatically changed over the years. The key issues of accountability and transparency are, in a sense, timeless. Early legislators, like their current counterparts, instituted a regime in which the public was able to discover the amount of money spent by political participants. They instituted a system in which those people and organisations assisting political participants in their quest for election were also subject to this requirement. Those same legislators foresaw the importance of election advertising as a crucial component of the sums of money the participants were required to spend. In recognition of the importance of the media for the dissemination of the electoral message, they imposed specific obligations on members of the media.

The only concern that the original and current legislators do not, on the face of the legislation, seem to share, is in relation to spending limits. However the existence of limits on expenditure indicates that, at the very least, there is historical precedent for their existence. Moreover these limits existed for some 80 years of this century as a central plank of the first system of campaign finance regulation introduced in Australia and survived (albeit in outdated form) for almost the entire century until they were repealed in $1980 .{ }^{46}$ They existed in the context of a system

42 Id at inserting s172A(2) into the Principle Act

43 Id at inserting s172B into the Principle Act.

44 Id at inserting $\operatorname{sin2B}(2)$ into the Principle Act.

45 Commonwealth Electoral Act 1902 s173(ii).

46 Commonwealth Electoral Amendment Act 1980. 
that was fairly described as a representative democracy. ${ }^{47}$ Their persistence for some 80 years suggests that although their practical workability may have been questioned, this did not lead to a desire for their repeal. They were not perceived of as inconsistent with constitutional democracy, or incompatible with the aims of the campaign finance system. The reinstatement of expenditure limits would not so much involve the introduction of an entirely new principle of campaign finance, as the mere restoration of an historical precedent, compatible with Australian notions of representative democracy.

\section{B. Expenditure Limits and the Development of Constitutional Free Speech}

The discussion so far assumes a somewhat static view of constitutional interpretation - expenditure limits were constitutional in 1902 and so they ought to be so now. Another, more evolutionary approach to constitutional interpretation, ${ }^{48}$ might suggest a different result. According to this view, the restriction upon legislative power derived from the implied constitutional freedom of political communication, which had its genesis in Australia in $1992^{49}$ and was reaffirmed in $1996,{ }^{50}$ may bar the re-introduction of expenditure limits. Adopting a similar line it has been successfully argued in the United States that any restriction upon campaign expenditure amounts to a breach of the First Amendment to the United States Constitution, which provides that Congress shall not abridge, to any extent, the right to speech. ${ }^{51}$ However it would seem unlikely that this argument would succeed in Australia for a number of reasons.

First, as a matter of historical intent the argument would probably fail. The enactment of the electoral expense limitation in 1902, almost contemporaneously with the enactment of the Constitution, suggests that if there was any conflict between the two instruments the legislators at the time, and indeed the legal fraternity at large, did not recognise it.

Second, practice mitigates against the free speech argument. The electoral provision existed for some 80 years without challenge, again indicating either a degree of myopia of the legal fraternity, or the constitutional validity of provision.

Third, there is the specific nature of the Australian free speech right to consider. Unlike its US counterpart the Australian freedom is not a free speech right at large, but an implied right to communication in relation to political matters, specifically in connection with those matters concerned with the maintenance of the system of representative democracy. ${ }^{52}$ So, for example, the limitation protects

47 Stephen $\mathrm{J}$ : it is 'quite apparent that representative democracy is descriptive of a whole spectrum of political institutions, each differing in countless respects yet answering to that generic description': Attorney-General (Cth) (Ex rel McKinlay) v Commonwealth(1975) 135 CLR 1 at 57.

48 As shown by Sue v Hill [1999] HCA 30, and Deane J in McGinty v Western Australia (1996) 186 CLR 140.

49 Nationwide News Pty Ltd v Wills (1992) 177 CLR 1; Australian Capital Television Pty Ltd v Commonwealth (1992) 177 CLR 106.

50 Lange v Australian Broadcasting Corporation (1997) 198 CLR 520.

51 Buckley $v$ Valeo (1976) 424 US 1.

52 The Court in Lange v Australian Broadcasting Corporation (1997) 198 CLR 520 at II 12. 
the making of the direct choice by the people of their political representatives ${ }^{53}$ It extends to protecting the electors against a complete prohibition on the political advertising which is essential to voters' choice because it provides them with information necessary for the making of that decision. ${ }^{54}$ However, the High Court has been unequivocal that freedom of political communication only exists to the extent necessary to protect the representative democratic system of government. It is not a freedom akin to the US form, which protects many types of speech. Hence in order to argue that expenditure limits were unconstitutional it would have to be shown that unlimited election expenditure was necessary for the maintenance of a system of representative democracy. This would be difficult to prove for two reasons. First, the High Court would have to first accept that election expenditure is a form of speech. Second, it would have to accept that unlimited election expenditure is a form of speech necessary to representative democracy.

Parallels might be drawn with other forms of conduct, such as political protest, which have been found to constitute a form of communication for the purposes of the protection. For example, in Levy's Case ${ }^{55}$ at least two members ${ }^{56}$ of the Court explicitly recognised that the communication covered by the implied freedom is not limited to traditional speech, but may include other conduct. Hence it may well be possible to argue that the spending of money constitutes a form of conduct which amounts to communication.

However this may depend on the type of conduct involved and its link to that crucial underlying feature of the Australian freedom, representative democracy. In Levy it was possible to show that protest is a form of conduct covered by the freedom, because political protest (even in relation to an issue such as duck shooting) is a recognised form of political communication and therefore integral to the democratic system. The expenditure of money, even by political participants, may not be quite so simple to categorise. Traditionally money is considered to be part of the field of commerce rather than politics and the spending of money is not conventionally seen as an essentially political act. However this obstacle may be overcome in view of the fact that the expenditure is being created by the political participants. This latter factor clearly provides the link to the representative democracy system that is missing in relation to other forms of expenditure, and suggests that campaign expenditure may indeed constitute communication for the purposes of the implied freedom.

Assuming that this is the case, and campaign expenditure does constitute communication for the purposes of the implied freedom, the next question would be whether this form of communication is necessarily protected by a freedom which only extends as far as the protection of representative democracy? Even if it is political speech, is it speech necessary for the maintenance of representative democracy? The Australian High Court has, on more than one occasion expressed

53 Australian Capital Television Pty Ltd v Commonwealth (1992) 177 CLR 106 (Dawson J), and confirmed in Lange v Australian Broadcasting Corporation (1997) 198 CLR 520.

54 Australian Capital Television Pty Ltd v Commonwealth (1992) 177 CLR 106.

55 Levy v Victoria (1997) 189 CLR 579.

56 Id at 107 (McHugh J), 157 (Kirby J). 
the view that there are a wide variety of models of representative democracy, the essential features of which are not set in stone. ${ }^{57}$ In some models of representative democracy unlimited campaign expenditure might be seen as an integral part of the communication between the representatives and the represented in order for the latter to directly choose the former. However it has also been argued that some models of representative democracy countenance restrictions on expenditure for the very reason that electoral choice cannot be made in the face of unlimited campaign expenditure because it has the potential to compromise the integrity of the political process. ${ }^{58}$ The Supreme Court of Canada has, in principle, recognised the validity of State referendum expenditure limits as a means of ensuring electoral fairness because it was a key component of political equality under representative democracy. ${ }^{59}$ Quoting extensively from the Lortie Commission, established to investigate Canadian electoral systems, it said:

If the principle of fairness in the political sphere is to be preserved, it cannot be presumed that all persons have the same financial resources to communicate with the electorate. ... To ensure a right of equal participation in democratic government, laws limiting spending are needed to preserve the equality of democratic rights and ensure that one person's exercise of the freedom to spend does not hinder the communication opportunities of others. Owing to the competitive nature of elections, such spending limits are necessary to prevent the most affluent from monopolizing election discourse and consequently depriving their opponents of a reasonable opportunity to speak and be heard. Spending limits are also necessary to guarantee the right of electors to be adequately informed of all the political positions advanced by the candidates and by the various political parties. ${ }^{60}$

Given then that there are a variety of models of representative democracy, some of which allow for expenditure limits and some of which do not, and assuming that any legislation would not prohibit completely all expenditure, it would be difficult to argue definitively that an expenditure limit necessarily breaches the Australian implied freedom of political speech (which embodies representative democracy). The most that could be said against reinstating expenditure limits is that they are not part of the 'core' of representative democracy, ${ }^{61}$ and therefore could not be subject to review on the basis of the implied freedom.

57 Attorney-General (Cth) (Ex rel McKinlay) v Commonwealth (1975) 135 CLR 1, McGinty v Western Australia (1996) 186 CLR 140.

58 A species of this argument was accepted by Brennan J in ACT TV when he upheld a prohibition on election advertising as a form of reasonable regulation: Australian Capital Television Pty Ltd $\checkmark$ Commonwealth (1992) 177 CLR 106 at 159-161.

59 Libman v Quebec, 1997 DLR LEXIS 1511: 151 D.L.R. $4^{\text {th }} 385$. Note however that the particular legislative limits under consideration here were struck down as disproportionate to their stated objective.

60 Id at $\lceil 47$.

61 See George Williams, 'Sounding the Core of Representative Democracy: Implied Rights and Electoral Reform’ (1996) 20 MULR 848. 
Another way of addressing the issue is to argue that even if expenditure limits are seen as, prima facie, a breach of the implied freedom because they burdened freedom of communication about political matters, ${ }^{62}$ they may yet be saved on the basis that they can be considered 'reasonably appropriate and adapted to serve a legitimate end the fulfilment of which is compatible with the maintenance of representative government. ${ }^{63}$ It might be possible therefore, to argue that preservation of the integrity of the political process is a legitimate aim compatible with representative government, and that expenditure limits are a proportional measure to achieve that goal. In this respect the Courts' earlier invalidation of a prohibition on election advertising might lead a current Court to view expenditure limits as a less drastic measure for achieving a similar goal, and valid on that account. Again, relying on Canadian jurisprudence, an argument might be made for reasonable regulation of speech on the basis of ensuring political equality between candidates, or voters' rights to receive information in order to ensure fairness of the electoral process. ${ }^{64}$

Finally, recent United States First Amendment decisions suggests a limited, but notable, softening of the US Supreme Court's formerly strict approach to free speech regulation where other public values are at stake, such as increased public discussion or prevention of electoral corruption. In one case it was suggested by some members of the Court that free speech may be regulated in circumstances where that regulation increases opportunities for public discussion and informed deliberation, because these values are the underlying goals of the First Amendment. ${ }^{65}$ One critic has commented that under this approach a cap on campaign expenditures would be valid:

[S]o long as Congress could reasonably conclude that it would enhance equal participation in public debate, and did not burden substantially more speech than necessary to achieve it[s] goal of equal participation. ${ }^{66}$

More recently, in the specific field of campaign finance, the Supreme Court reaffirmed its long-standing distinction between contribution limits (which are constitutional under certain conditions) and spending limits (which are not) ${ }^{67}$ and, in the process, reiterated the importance of allowing legislatures to limit campaign contributions for the purpose of combating real and potential corruption attributed to permitting large contributions into the electoral process. ${ }^{68}$

In short even given any political antipathy toward expenditure limits, constitutional doctrine does not necessarily bar their re-introduction in Australia.

62 Above n58.

63 Ibid.

64 Above $n 59 \& 60$.

65 Turner Broadcasting System v FCC, 117 S. Cl. 1174 (1997).

66 Andre R Barry, 'Balancing Away the Freedom of Speech: Turner Broadcasting System v FCC, 117 S. Ct. 1174 (1997)' (1998) 21 Harvard Journal of Law and Public Policy, 285 at 286, notes omitted.

67 In reaffirming the distinction, the Court referred back to Buckley $v$ Valeo 424 US 1, and to the more recent decision of Colorado Republican Federal Campaign Comm. v FEC, 518 US 604.

68 Missouri v Shrink Missouri Government PAC, 120 S. Ct, 897 (2000). 


\section{Commonwealth Regulation, Deregulation, Revival and Expansion}

Putting the constitutional issue to one side, the early legislation covered all the pertinent aspects of campaign finance and the next 80 -odd years of regulation were relatively uneventful in a legal sense. With only a few changes to the legislation, the situation could be described as relatively dormant. In 1946 the expenditure limit was increased to $£ 250$ in the case of the House of Representatives and $£ 500$ in the case of the Senate, ${ }^{69}$ and the categories of authorisable electoral expenses were broadened to include 'advertising and broadcasting' as well as the more traditional methods of dissemination of campaign information. ${ }^{70}$ These were simply moves to keep up with the changing times, both inflationary and technological, and reflected a degree of satisfaction with the goals and methods of the original legislation. Similar moves were made in 1966, when the introduction of decimal currency led to the expenditure limit being revised to $\$ 1000$ for the Senate, and $\$ 500$ for the House of Representatives. ${ }^{71}$

Few other noteworthy changes were made to the Commonwealth Act in the next half-century. One of these was a prohibition on what is referred to colloquially as 'porkbarrelling'. In 1966 there was inserted into the legislation a prohibition upon candidates making gifts to clubs or associations. The penalty was, even by 1966 standards, extremely low, namely a $\$ 10$ fine, although it was supplemented by 'any other penalty provided by law' and there was a three-month limitation period on bringing claims. ${ }^{72}$ All penalties were raised in 1980 to $\$ 100$ for failure to comply with the section and $\$ 200$ for untrue statements. ${ }^{73}$

\section{A. Virtual Deregulation - A Brief Interlude}

The dormant phase came to a close in 1980 with the repeal, albeit briefly, of campaign finance regulation. All of Part XVI of the 1918 Act, except for the section requiring newspaper proprietors to furnish returns, was deleted from the statute books. In the process campaign expenditure limits and the requirement for electoral expenditure returns were removed. ${ }^{74}$ This 'virtual deregulation" ${ }^{, 75}$ came as the result of a fear that substantial non-compliance with the legislation (common amongst both candidates and organisations) could lead to national challenges, ${ }^{76}$ following a successful challenge by the Australian Democrats to the election of a candidate to the Tasmanian Parliament under that State's laws, causing a byelection to be held. ${ }^{77}$

69 Commonwealth Electoral Act No. 421946 s 4

70 Ibid.

71 Commonwealth Electoral Act 1918 as amended by Commonwealth Electoral Act 1966.

72 Id at s150, s172A(5)-(7).

73 Commonwealth Electoral Act No. 93 (1966) s3.

74 Commonwealth Electoral Amendment Act (1980) s4

75 Denny Meadows, 'Open election funding or hide and seek?' (1988) 13(2) Legal Services Bulletin 13(2) 65 at 65 .

76 Australia, Joint Select Committee on Electoral Reform, First Report (Canberra: 1983) at 28.

77 Id at 65 (Colin Hughes). 
However deregulation was also accompanied by the government's stated aim to introduce a form of public disclosure of campaign expenditure, and to this end the matter was referred to an independent inquiry, which reported to the government in 1981 and was made available to the Parliament in $1983 .^{78}$

Thus after nearly 80 years spending limits were erased from the landscape of Australian political history because a) they were often not complied with; b) the danger of electoral instability arising from an increase in successful challenges to elected candidates on their basis of non-compliance; and c) the government aimed to overhaul the entire system. The erasure of spending limits may lead some current commentators to believe that limits are new to Australian politics, when in fact they were in existence for more of the post-Federation period than they have been absent.

In any event, the release of the report by the Joint Select Committee on Electoral Reform in 1983 led to a major revamping of campaign finance. In its opening chapter the Committee commented that although electoral reform had not 'atrophied' it perhaps had 'not progressed at a rate in line with expectation' ${ }^{79}$ Accordingly the Committee recommended the introduction of a whole new system which included public funding and disclosure rules. ${ }^{80}$ Although the legislation was largely well received, one commentator commented, prophetically, that there were 'more direct ways to control campaign costs', citing as an example a prohibition on paid broadcast electoral advertising. ${ }^{81}$

\section{B. The Introduction of Public Funding}

The major innovation of the 1983 amendments was the introduction of a system of public funding for political candidates and parties. In its report the Joint Committee acknowledged that indirect public subsidisation of the political process already occurred. ${ }^{82}$ Campaigns were indirectly funded as a result of compulsory voting (which saved parties a major expense in organising voter drives); access to electoral rolls; tax deductability of candidates' election expenses; and public provision of basic infrastructure needs for campaigning such as staff, telephones, offices, postage, and research. Nevertheless, a majority of the Committee concluded that public funding for electoral expenditure was warranted, ${ }^{83}$ although they stopped short of recommending funding for ongoing administrative maintenance. $^{84}$

The public funding system was to be based upon a number of foundational principles. Money was payable only to those with significant electoral support; it was payable according to fixed rules; the amount received would be related to

78 Ibid.

79 Id at 29.

80 The main provisions relating to disclosure are carefully summarised and analysed in Meadows, above $\mathrm{n} 75$ at 68

81 Ibid.

82 Above $\mathbf{n} 76$ at 145 .

83 Id at 152 .

84 Id at 157. 
electoral support and funds would not exceed election expenditure. ${ }^{85}$ Participants would have to receive at least 4 per cent of the primary vote to qualify for funding which was to be calculated using a base rate linked to an indexed postage rate. It was to be paid to an accountable person in the appropriate party organisation, or where none existed, to the candidate. Only registered political parties and candidates could apply for funding; evidence of expenditure had to be provided; no advance payments were to be made; and the system was to be administered by the Australian Electoral Commission. ${ }^{86}$

In reaching its recommendations the Committee accepted a range of arguments the empirical basis of which is not to be found in the Report but which we have sought to test with a set of interviews with political participants, regulators and observers. ${ }^{87}$ For example the Committee relied on the view that public funding would help avert the taint of the influence of money upon the political process. It said funding could help participants avoid donations by large and specialised interest groups, ${ }^{88}$ and therefore it would reduce 'the necessity or temptation' to accept donations with conditions attached. ${ }^{89}$ While it is not possible to state definitively that this view has or has not been borne out in the years subsequent to the introduction of funding, anecdotal reports would suggest that public funding has not diminished political participants' enthusiasm for seeking donations from large or specialised interest groups. ${ }^{90}$ Nor, according to a 1991 report of the successor Committee had it led to a much greater_degree of transparency generally in the system. ${ }^{91}$ Whether public funding has reduced the temptation to accept conditional grants is impossible to test because, as we discussed above, the

85 Id at 156.

86 Id at $156-160$.

87 Peta Stevenson, interviews with Doug Thompson, ACT Branch Secretary, Australian Labor Party (Canberra, 8 December 1998); Phil Orphin, Accountant and Party Agent, National Party (NSW Branch), (Sydney, 14 December 1998); Andrew Bartlett, Senator and Federal Campaign Director for the 1998 Federal Election, Democrats (Queensland, 15 December 1998); Mike Steketee, National Affairs Editor, The Australian (Sydney, 10 December 1998); Ian McKenzie, NSW Campaign Coordinator for the 1998 Federal Election, former NSW and Australian Greens Treasurer and Party Agent, Greens (Canberra, 18 December 1998); Party Official, NSW Liberal Party (Sydney, 18 December 1998); David Oldfield, Adviser, One Nation Party, (10 December 1998), Professor Rolf Gerritson, Professor of Local Government and Applied Policy, Australian Centre for Regional and Local Government Studies, University of Canberra (Canberra, 17 December 1998); Brad Edgman, Director of Funding and Disclosure, Australian Electoral Commission (Canberra, 14 December 1998).

88 Above $\mathrm{n} 76$ at 154 . However, Mike Steketee feels that public funding has simply created new methods of hiding sources of donations: Peta Stevenson, interview with Mike Steketee, ibid.

89 Above 76 at 153 .

90 For example see evidence that in the 1987 federal election the Australian Labor Party received public funding of almost $\$ 5 \mathrm{~m}$ and donations of approximately the same amount; the Liberal Party received public funding of $\$ 4 \mathrm{~m}$ and the same again in donations and the National Party received $\$ 1.2 \mathrm{~m}$ in public funding and $\$ 1.7$ million in donations: Australia, Joint Standing Committee on Electoral Matters, Who Pays the Piper Calls the Tune-minimising the risks of funding political campaigns : Inquiry into the Conduct of the 1987 Federal Election and 1988 Referendums, Report No. 4 (Canberra: June 1989) at Table 7.1, 74.

91 In its 1989 report the Committee stated there remained an 'alarming lack of information of sources of election funding': id at 76. 
influence of money on politics is only one in a range of variables that may affect public policy making. ${ }^{92}$ Our hypothesis here is not that money does corrupt politics but that the imputation that it could is enough to warrant regulation to stop or at least stem the flow of private money into political campaigns.

The record is also probably a little harsh on another of the Committee's justifications for funding, namely to assist parties in financial difficulties. ${ }^{93}$ Although public funding must help parties, particularly new parties, to gain sufficient financial momentum to run a campaign, ${ }^{94}$ large parties which spend large sums of money may still experience financial difficulties under a system of public funding. Conventional wisdom has it that an impetus behind the Australian Labor Party's introduction of the Political Broadcasts and Disclosures Bill 1991 (which prohibited political advertising during election campaigns subject to limited exceptions) was the high level of the party's indebtedness after the 1990 election campaign due, in large part, to the high cost expended upon broadcast advertising. This financial shortcoming arose during the period of public funding, which suggests that public funding may not be the magic wand that the 1983 Committee seemed to assume that it was. It must be said, however, that most of the party representatives interviewed were fundamentally positive on the impact of public funding on the opportunities for smaller parties and those in financial difficulties. Public funding was thought to provide a degree of certainty for parties, without having to seek corporate sponsorship. One commentator suggested that parties such as the Democrats might not exist without public finding. ${ }^{95}$ This was certainly a claim supported by the Australian Electoral Commission's Director for Funding and Disclosure ${ }^{96}$ and also by David Oldfield from the One Nation Party who was in a position to fully understand the financial concern of smaller parties which may be unable to gain the same level of corporate sponsorship as the ALP or the Liberals. ${ }^{97}$

Other justifications relied upon by the Committee were the existence of similar schemes in other countries, and the equalisation of opportunities between parties. In relation to the comparative argument, it appears that a range of countries

92 It is further complicated by the fact that virtually all parties contend that conditional grants are unacceptable and unaccepted. Peta Stevenson, interviews with Doug Thompson, Phil Orphin \& Andrew Bartlett, above $\mathrm{n} 87$. Senator Bartlett also stated that there are a few areas the Democrats simply refuse to accept money from, such as tobacco, uranium, and wood-chipping; lan McKenzie \& Party Official, NSW Liberal Party, above 87.

93 Above $n 76$ at 154.

94 Interestingly enough, this is supported by the ALP and the Democrats (Peta Thompson, interviews with Doug Thompson \& Andrew Bartlett, above n87) but contested by the smaller, newer parties, the Greens and One Nation (Peta Thompson, interviews with Ian MacKenzie \& David Oldfield, above $\mathrm{n} 87$. Both of them see major problems because most new parties seeking serious representation start in the upper house, where it is very difficult to get the requisite 4 per cent support. This is compounded by the fact that public funding is not available in advance, but only after the election if you achieve the magic 4 per cent.

95 Peta Stevenson, interview with Professor Rolf Gerritson, above n87.

96 Peta Stevenson, interview with Brad Edgman, above n87.

97 David Oldfield claimed that the One Nation Party ran its campaign solely on public funding as they had no corporate donations whatsoever: above $n 87$. 
continue to maintain public funding systems. The equality argument continues to be strongly argued in the American context, ${ }^{98}$ but no empirical studies appear to have been done to test the hypothesis that the greater the source of public funding available to support new participants into an increasingly expensive political process the more likely a wider range of people will be able to participate. However our interviews suggested that whilst public funding did assist small parties, 'it has also put money in the coffers of big parties'. ${ }^{99}$ What does remain certain is that in countries where public funding does not exist the cost of entering the political contest is extremely high, is increasing every year and probably remains out of the reach of ordinary people. ${ }^{100}$

One final justification for the introduction of public funding seems to have been fairly weak even at the time of the Report, and that is the view that public funding would reduce reliance upon fundraising in order to allow greater concentration on policy development. ${ }^{101}$ Again it would be hard to test this proposition but it would seem unlikely that the political fundraiser is any less of an institution in an environment of public funding and that any spare moments away from it are being spent on policy development. Moreover, policy development tends to occur separately from fundraising. The modemisation of the fund-raising process and its increasing importance to parties means that such processes are frequently handled by a specialised wing of the party, ${ }^{102}$ and bear very little relation to those areas specialising in policy development.

The final recommendation of the Committee in relation to public funding was for further consideration to be made of the view put in evidence before it that no public funding be introduced but that free time be granted to all participants and that all political advertising be banned. ${ }^{103}$

However plausible were the justifications for public funding, in 1983 it was introduced as part of the Commonwealth Electoral Legislation Amendment Act 1983.

The provisions relevant for our purposes were contained in Part XVI of the Act entitled 'Election Funding and Financial Disclosure'. The Part was divided into six divisions dealing with: election funding; disclosure of donations; disclosure of electoral expenditure; interpretation of the legislation; agents; and other miscellaneous matters including penalties, public access to documents, and indexation of funding.

98 'Wealth Robs the Unwealthy of Voting Clout', Los Angeles Times (26 July 1994).

99 David Oldfield, above n87. Ian MacKenzie (above $n 87$ ), of the NSW Greens also believes that there is such a huge gap between the Greens and the major parties that it is impossible to truly level the playing field.

100 For example, according to the US Federal Election Commission, in 1996 the cost of running for a seat in the US Senate was \$US3.76 million. Quoted by the Washington Post (4 September 1998): <http:/Www.washingtonpost.com/wp-srv/politics/special/campfin/campfin.htm>.

101 Above $\mathbf{n 7 6}$ at 155.

102 Peta Stevenson, interviews with Doug Thompson, Phil Orphin \& David Oldfield, above n87.

103 Above $n 76$ at 161 (evidence of Professor Joan Rydon). 
The key sections were contained in Divisions 3,4 and 5. Division 3 established a system of partial public funding of election campaigns under which parties, candidates and groups had a general entitlement to funds. Funding was provided for candidates and groups who received over 4 per cent of the primary vote. ${ }^{104}$ Once that threshold was reached the participants received public funding which varied according to the number of formal, first preference votes they received. House of Representatives candidates received the highest base payment, then Senate candidates elected during an election not held simultaneously with the House of Representatives election and then Senators elected during a simultaneous election. ${ }^{105}$ Payment was made on the basis of 'total electoral expenditure', and was not to exceed this amount. ${ }^{106}$ Hence claims had to be made in the approved form accompanied by information showing the exact total electoral expenditure of the political participant. ${ }^{107}$ Standard reimbursable items included extra salaries and campaign novelty items, but excluded publicity for a membership drive and post election parties. ${ }^{108}$ The agent of the registered party, candidate or group was responsible for making the claim ${ }^{109}$ and receiving the payment. ${ }^{110}$ Claims for payment could be made up to 20 weeks after polling day. 111

\section{Disclosure of Donations}

The Joint Committee's discussion of disclosure was noteworthy because it included some consideration, albeit short, of disclosure of income and of administrative expenditure. Although neither matter was finally incorporated into the Committee's recommendations for disclosure, their existence in the deliberations indicates the scope that remained for extending the disclosure requirements.

The Australian Labor Party put forward to the Committee the view that disclosure of all income was an 'essential corollary' to public funding because the 'long term viability of the democratic system depends on public confidence in the legitimacy and integrity of the political process and that any hint of corruption undermines public confidence'. ${ }^{12}$

The Liberal Party argued that disclosure of donations constituted a 'grave infringement of civil liberties', a 'violation of privacy', and that it carried the threat of 'victimisation of individuals particularly by certain trade unions'. 113 It

104 Commonwealth Electoral Legislation Amendment Act 1983 s153B.

105 There is an entitlement to a base rate of 60 cents per vote for elections to the House of Representatives; 30 cents for elections to the Senate where the polling day is the same as the House; and 45 cents for election to the Senate where the Senate election is not coincidental with the House election: $\mathbf{s} 152(1)-(3)$.

106 Section $153 \mathrm{C}$.

107 Section 153(8)(a) and (b).

108 Australian Electora] Commission, Election Funding and Financial Disclosure Handbook (Canberra: AGPS, 1984) at 16-17.

109 Section 153.

110 Section 153D.

111 Section 153(8)(c).

112 Above $n 76$ at $162-163$.

113 Id at 163. 
proposed, therefore, that only donations above $\$ 10000$ be subject to disclosure regulations. ${ }^{114}$ Although the national, and some state, bodies of the National Party accepted the principle that undisclosed donations could potentially corrupt the political process other branches did not. The Queensland branch for example was totally opposed to disclosure of donations.

The majority of the Committee accepted the view that donations could potentially influence the political process and so public disclosure was necessary for the preservation of the integrity of the system. 115

A number of recommendations in relation to disclosure of donations were made. Disclosure should be made of donations above $\$ 200$ to a candidate or above $\$ 1000$ to a party. The total amount of donations received by candidates, or parties should be disclosed. The Committee recommended a prohibition on anonymous donations with the requirement that, if received, anonymous donations should be forwarded to the Electoral Commission. They also recommended that all receipts or donations received or paid above prescribed levels by organisations or individuals (what the Report called 'front' organisations) should also be disclosed. Agents should be registered by political parties and candidates, and one of their functions would be to furnish disclosure returns. Administration and regular reporting to Parliament was to be made by the Electoral Commission. Innocent mistakes in returns were not to be penalised but severe penalties would be applied for submission of knowingly false returns. ${ }^{116}$

The Committee rejected any requirement for disclosure of donations to party maintenance or administrative expenditure provided they were not used for election purposes. ${ }^{117}$ This loophole continues to the present day.

\section{Disclosure and Third Parties}

In any event the disclosure provisions contained in Divisions 4 and 5 of the Act, followed the Committee's recommendations quite closely. Division 4 dealt with disclosure of donations. It established a system where all political parties, State branches of political parties, candidates, and groups running in an election were obliged to reveal details of any gifts received. In the case of political parties or State branches, they were obliged to disclose details of all gifts unless they were under $\$ 1000$, or made on condition that the gift be used for a non-election purpose. ${ }^{118}$ Candidates were to reveal all gifts over $\$ 200$ and groups all gifts over $\$ 1000 .^{119}$ Independent interests were also required to reveal on the public record any expenditure over $\$ 1000$ incurred for a political purpose.

118 Commonwealth Electoral Legislation Amendment Act $1983 \mathrm{~s} 153 \mathrm{~J}(5)$.

119 Section $153 \mathrm{~J}(5)$. 
Disclosure covered a variety of matters. It stipulated that, amongst other things, the total amount of all gifts received, the number of gifts, and the 'relevant details' of each were to be listed on the return.

The legislation also targeted donors who 'split' gifts in order to avoid disclosure. If a donor gave two or more gifts during the disclosure period, with a total value of $\$ 1000$ or more, then the details of each must be provided. The term 'gift' was defined in the interpretive section to mean 'any disposition of property otherwise than by will, being a disposition made without consideration or with inadequate consideration'. ${ }^{120}$ It included the provision of a service, other than volunteer labour. It did not include public funding, or annual subscriptions.

The Electoral Commission Handbook also made it clear that the definition of gift included gifts-in-kind and that they should be valued at the cost to the donor or, where no cost was involved (such as office space) on the basis of income foregone. ${ }^{121}$ Candidates' contributions to their own campaigns were not disclosable. ${ }^{122}$

Disposition of property was defined to cover any conveyance, transfer, assignment, settlement, delivery, payment or other alienation of property. A list of types of property caught by the definition then followed although it was not exhaustive. The list includes: shares; trusts; lease, mortgage, charge, servitude, licence, powers, partnership or interest; the release of any debt, contract or chose in action; general powers of appointment; and any transaction entered into with intent to diminish the value of property and increase the value of another person's property. 123

Disclosure was to be made by the participants' agent through the making of a return to the Electoral Commission. ${ }^{124}$

The period for which disclosure was to be made varied. Political parties and state branches had to disclose all gifts received in the period from the day after polling in the last election up to polling day in the current election. ${ }^{125}$ A first-time independent candidate had to disclose all gifts received since they announced their candidature. ${ }^{126}$ An incumbent independent had to disclose all gifts received from the day after polling in the last election in which they stood. ${ }^{127}$

Despite the breadth of the legislation it contained a number of 'avoidance techniques'. ${ }^{128}$ These included the exclusion from the disclosure requirement of membership subscriptions, importantly, loans and income derived by a party from

120 Section $153 \mathrm{H}$.

121 Above n108 at 19.

122 Section $153 \mathrm{H}(3)$.

123 Section $145(1)$.

124 The return had to be made before 20 weeks after polling for political parties and state branches: s153J(1); 15 weeks for independent candidates and groups: s153J(2)(3) and for independent interests: s153K.

125 Section $153 \mathrm{~J}(1)$.

126 Section $153 \mathrm{~J}(2)(\mathrm{a})$.

127 Section $153 \mathrm{~J}(2)(\mathrm{b})$.

128 Meadows above $n 75$ at $68-69$. 
its investments or business undertakings. Large amounts of money used in campaigns could still go undetected because of the broad exception for gifts made for purposes other than a purpose related to an election. ${ }^{129}$ Moreover a donor could give a party a large sum with the express purpose of investing it and thus avoid the disclosure provisions, even if the money derived from that investment was used for election purposes. Finally, the exclusion of party maintenance or administrative expenditure funds from disclosure in the interests of administrative simplicity, was seen as a 'loophole': 130

It is difficult to see how a requirement of full annual accounts from parties, who presumably must account to their members, would significantly complicate the system for the Commission or for the honest party. ${ }^{131}$

The same commentator also noted that the level at which the identity of small donors must be revealed was generally higher in the Australian legislation than in its US counterpart; ${ }^{132}$ that third parties were not required to disclose campaign contributions to primary participants under the legislation's definition of electoral expenditure; ${ }^{133}$ and that the requirement under the Act to keep records was 'far from rigorous'. 134

The 1984 Handbook also excluded other items from disclosure, although it does not make clear upon what basis it made the assessment since some items could have fallen within the notion of gift, and yet were not specifically excluded by the legislation. For example, Meadows has commented that 'income derived by the party from investments or business undertakings', which the Handbook excluded, could constitute a gift for the purposes of the legislation. ${ }^{135}$ The exclusion of cash raised in ad hoc collection also became somewhat problematic in the light of evidence that senior Queensland party officials received large cash donations in brown paper bags. Loans, too, might have constituted a gift, especially if they were subsequently not enforced. Offers by media to interview candidates raised the spectre of donations in the light of the known, partisan, sentiments of certain large media groups, and in view of their highly diversified and complex business interests. Media groups, who could no longer be solely identified as reporting on society because of their interconnecting interests in other commercial sectors could have been seen as making an offer resembling donation in-kind which amounted to a valuable contribution and yet avoid disclosure.

Gaps can also be found around the provision of services that are seen by the Handbook as examples of volunteer labour. Included here was time spent on party activity by a person who was also a director of a public company; time spend by a trade union official (except where seconded for the campaign); legal or financial

129 Ibid.

130 Ibid.

131 Ibid.

132 Ibid

133 Ibid.

134 Id at 70.

135 Id at 68-69. 
advice provided by a lawyer or accountant who was a party member; printing services. Effectively, if a party could find party members who are also printers, lawyers, financial advisers, trade unionists or managing directors, they could, indirectly at least, avoid the full brunt of the disclosure provisions. ${ }^{136}$

\section{E. Disclosure of Expenditure}

The other method introduced to reinforce the integrity of the new public funding system was the introduction of an obligation to disclose expenditure. Although campaign election expenditure limits had been in place between 1902 and 1980 , the limits had been set at the 'ridiculously low'137 levels of $\$ 1000$ for a Senate candidate and $\$ 500$ for a House of Representatives candidate, and they were unenforceable. In 1980 the government established an inquiry into electoral expenditure headed by Sir Clarrie Harders, a retired senior public servant. Expenditure limits were not within its terms of reference, and instead the inquiry focused upon the introduction of a system of disclosure. The Joint Committee of 1983 reported that implementation of the Harders system of recommendations was 'not desirable', although it is not entirely clear from the 1983 Report's summary of the Harder's report what options the 1983 Committee rejected. However, the 1983 Report carries a lengthy explanation as to why disclosure of party administrative and maintenance funds on an annual basis should be rejected as this was the main recommendation on which the Committee Report differed from the Harders Report. In essence the Committee said that there was no need to require full annual accounts of party expenditure because this information was already available. A little unconvincingly the Committee states: '... most information would in non-election years relate to party maintenance functions. 138

The Committee even recognised that the exemption may 'be seen as a way round the disclosure provisions' but it optimistically predicted that 'public revelation of practices of this kind with its attendant opprobrium should provide sufficient deterrent'. ${ }^{139}$

The Committee rejected the re-introduction of expenditure limits on the basis that they were 'unenforceable' in Australia and overseas (although does not adduce any evidence for this claim) and that in any event the new scheme would render limits 'superfluous'. 140

Expenditure disclosure was, however, to be made by political parties, candidates, interest groups and other political participants ${ }^{141}$ in relation to costs of: television, radio and newspaper advertising (including production costs); authorised material; production and display of advertising at theatres etc; consultancies; and opinion polls. ${ }^{142}$ Also suggested for re-introduction was a

136 Above $\mathrm{n} 108$ at 20.

137 Above $n 75$ at $68-70$

138 Above $n 76$ at 172.

139 Ibid.

140 Ibid.

141 Id at 174

142 Id at 173. 
requirement that media and newspaper organisations disclose advertising space or time bought by candidates, parties and other participants during a campaign, and whether it was provided at less than normal rates. ${ }^{143^{\circ}}$ The Committee recommended that non-compliance with the legislation not be a ground of election invalidity on the basis that it would cause 'disruption to the political process', 144 but instead recommended a range of monetary penalties. ${ }^{145}$

The resulting legislation introduced compulsory disclosure of electoral expenditure by parties, state branches, independent candidates, groups, third parties, and media organisations.

The categories of expenditures which fell within the definition of this part of the Act were broadcasting, publishing, display and production of electoral advertisements; ${ }^{146}$ election related consultant's or advertising fees; opinion polls; and other research. ${ }^{147}$

All participants were required to furnish a return of electoral expenditure to the Commission. Parties and state branches had 20 weeks to do so, ${ }^{148}$ independent candidates, ${ }^{149}$ groups, ${ }^{150}$ and third parties ${ }^{151}$ had only 15 . Third parties were also required to do so, but only if the expenditure exceeded $\$ 200 .^{152}$

Broadcasters and publishers also had 15 weeks within which to submit a return to the Electoral Commission setting out the particulars of each advertisement including the station or journal of publication; the authorising participant; dates; and charges. ${ }^{153}$ They were also required to indicate whether or not the rate charged was less than normal commercial rates. ${ }^{154}$ Publishers were only required to furnish a return if the total amount of the charge exceeds $\$ 1000$. ${ }^{155}$

Again, returns by parties, state branches, independent candidates, and groups were to be submitted by their respective agents.

\section{F. Penalties and Remedies}

Failure to comply with any provision did not invalidate the election, ${ }^{156}$ however failure to furnish a donation or expenditure return could have resulted in a fine of up to $\$ 5000$ for a party or state branch, or $\$ 1000$ in any other case. Submission of an incomplete return was also an offence resulting in a fine of up to $\$ 1000$. The making of a donation or expenditure return, or a claim for public funding,

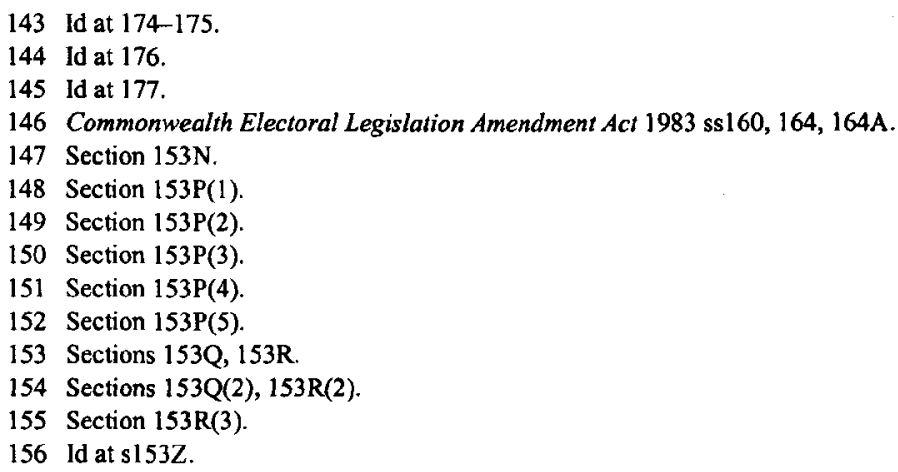


containing material which the agent knew to be false or misleading by an agent of a party or a state branch, carried a fine of $\$ 10000$. The same offence by others carried a maximum $\$ 5000$ fine.

\section{G. 1983-1991 - Maintenance and Fine-tuning}

Over the next eight years, between 1983 and 1991, the legislation was fine-tuned. It was renumbered in 1984, and the funding and disclosure provisions formerly contained in Part XVI became known as the Part XX provisions. ${ }^{157}$ The definition of broadcaster was clarified so as to include the holder of any licence within the meaning of the broadcasting legislation (other than a re-transmission licence), as well as the ABC and the SBS. 158

Three years later came further clarifications, but no dramatic change. Under the interpretive section an advertisement related to an election if it contained electoral matter, whether or not consideration was given to its publication; ${ }^{159}$ expenditure incurred for political purposes was disclosable if it was expended during a specified period now named a 'disclosure period' (rather than election period); ${ }^{160}$ and expenditure would be defined as incurred for political purposes when it involved publication by any means or publicly expressing views on an election issue, ${ }^{161}$ rather than the old text which required actual 'campaigning'. 162

\section{H. 1991 Political Broadcasts and Political Disclosures Act - Adbans, Compliance Audits ${ }^{163}$}

\section{(i) Expenditure Limits, adbans, and Free time}

Although the issue of expenditure limits had not been explicitly raised again since their repeal in 1980, the issue was very much in the background for the reforms of 1991. The year marked the next active stage of campaign finance reform when a prohibition on paid political advertising was introduced (along with the introduction of audits of annual disclosure returns by political parties, and of third parties' election returns). The advertising changes were brought about by a process which had commenced two years earlier, and which harked back to a recommendation of the 1983 Report to conduct an 'extended inquiry' into broadcasting and television in election campaigns so as to enable it to investigate "indirect public funding via "free" time and standards governing political

157 Commonwealth Electoral Legislation Amendment Act $1984 \mathrm{~s} 5$ and Table.

158 Broadcasting and Television (Consequential Amendments) Act 1985 s3 Schedule. The preexisting definition had differentiated between holders of commercial and public licences; whereas the new definition brought them all within the same urmbrella of simply being licence holders under the Broadcasting Act 1942.

159 Commonwealth Electoral Amendment Act 1987 s34.

160 Section 35.

161 Ibid.

162 Commonwealth Electoral Legislation Amendment Act $1983 \mathrm{~s} 113$, amending $\mathrm{s} 153 \mathrm{~K}$.

163 Parts of this section are based on an earlier publication by the Deborah Cass. 'Through the Looking Glass: The Right to Political Speech' in Tom Campbell \& Wojciech Sadurski (eds), Freedom of Communication (1994). 
advertising' ${ }^{164}$ Although this proposal was not specifically adopted, in 1989, as part of its general inquiry into the 1987 election, the Joint Committee on Electoral Reform instituted an investigation into political advertising specifically, claiming that issue had been raised by various submissions (including 'notably' the Australian Labor Party) ${ }^{165}$ - although this was disputed in a minority report. ${ }^{166}$ The Committee relied on an appeal to the principles of democracy to justify its investigation:

\begin{abstract}
The rising cost of television advertising time has coincided with the growing use of that medium for political advertising. This has greatly increased the reliance of parties on corporate sponsorship. The Committee is concerned that heavy reliance by parties on such sponsorship risks the distortion of our open democratic system. ${ }^{167}$
\end{abstract}

A majority of the Committee recommended that a system of free time be introduced for political broadcasting on television and radio during election campaigns. In a 'freewheeling' discussion they noted the pervasive influence of television in liberal democracies, ${ }^{168}$ especially during election campaigns, ${ }^{169}$ noting that this coincided with a dramatic increase in the costs of television advertising.

The costs of political advertising were explored briefly in Chapter 8 of the Report which noted three related problems: increased costs; scandals caused by improper fund-raising practices; and the potential for corruption. They noted the increasing gap between public funding and the amount needed to advertise during federal elections. While public funding had increased by 30 per cent in the period since its introduction in 1984, the advertising expenditure costs had risen by over 100 per cent. ${ }^{170}$ The Committee stated that: " $[t]$ he ability to buy television and radio advertising should not and must not play a determining part in federal elections. $^{171}$

Moreover the Report noted the corrupting influence money had played in overseas politics, mentioning the Recruit scandal in Japan and Watergate in the United States. Finally the Committee referred to the increasing US practices of politicians receiving substantial donations for public speaking engagements, or the charging of lobbyists to attend meals with members of Congress. ${ }^{172}$ They concluded:

164 Above n76 at 181.

165 Above $n 90$ at 19.

166 Id at 117. Dissenting Report by Mr Michael Cobb, MP, Senator James Short \& Dr Michael Wooldridge, MP.

167 Id at xi.

168 Id at 24 .

169 Id at 25.

170 Id at 86 .

171 Ibid.

172 Id at 88 . 
While there is no firm evidence of corrupt practice in Australian political fundraising, the substantial increase in the cost-pressures of campaigning create the potential for such practices. ${ }^{173}$

They concluded that the democratic process had become increasingly dependent on who could raise the substantial funds needed to buy advertising on electronic media. ${ }^{174}$ Although the Australian Broadcasting Corporation made some provision for free time to political parties, this was not required by legislation and was allocated on a discretionary basis, ${ }^{175}$ and the commercial networks provided no equivalent. ${ }^{176}$ The Committee made some rather cursory comparisons with other Western democracies, noting that some form of free advertising existed in many; that paid political advertising was permitted in only five of the 19 countries surveyed, and that Australia's system was the most 'laissez faire'. ${ }^{177}$ In passing, the Committee referred to the fact that in West Germany political parties had adopted a 'self-imposed ceiling' on election campaign financing, and that free time was allocated equally to all parties regardless of size. ${ }^{178}$ The majority report very briefly discussed and dismissed a range of options: increased public funding was discounted because the costs would be borne by the taxpayer and would need to be indexed to the costs of electronic media advertising; ${ }^{179}$ tax deductibility would only favour high income earners and would involve a revenue loss to the government; ${ }^{180}$ a ceiling on paid advertising could be subverted by political action committees (like the United States) which would be able to campaign for funds up to the stated ceiling; ${ }^{181}$ and a complete ban on paid advertising would have a 'direct effect on freedom of speech by reducing opportunities for discussion'. 182 Moreover it would lead to benefits for the existing major parties, and a reduction in commercial broadcasting revenue. ${ }^{183}$

Ultimately the majority recommended the introduction of a system of free time for political advertising on the basis that it was common to many western democracies, could be introduced without any revenue loss to broadcasters, involved no additional taxpayer expense, and would relieve pressure for increased political funding. ${ }^{184}$

The 'free time' system was to apply to both federal and state elections and operate only in the absence of any paid political advertising, and on the basis that all political parties accepting free time disclose fully their donations incomes and

173 Ibid.

174 Id at 25.

175 Id at 30-33.

176 Id at 33.

177 Id at 50.

178 Id at 48-49.

179 Id at 90.

180 Id at 91 .

181 Id at 91-92.

182 Id at 92.

183 Ibid.

184 Id at 93. 
expenditures. ${ }^{185}$ It was to be allocated by an independent committee, along the lines of the UK model, which would have discretionary powers ${ }^{186}$ but be limited by a formula based upon the level of support (measured in votes received) that the party received at the previous election. ${ }^{187}$ Foreseeing difficulties for new parties with significant support, the Committee recommended that those parties be able to apply for a percentage allocation of 5 per cent of the total amount of free time, as long as they nominated candidates for the Senate and for more than half the House of Representatives seats in any one state. ${ }^{188}$ This threshold for free time allocation for new parties was extremely high.

\section{(ii) Funding and Disclosure}

Also contained in the report in Chapter 7 were the Committee's findings in relation to the regularly reported issues of funding and disclosure.

One issue which remained contentious was spot audits. In the previous Committee's Report, it was concluded that existing powers were sufficient and there was 'no need for spot audits'. ${ }^{189}$ However the current Committee discussed the concern that parties might be avoiding the disclosure provisions, and there was no way for the Commission to know whether or not this was the case. The Commission likened its situation to viewing three walnut shells, only one of which was transparently labelled donation and the other two being opaque. Without the power to conduct spot audits there was no way for the Commission to determine whether the two opaque shells required investigation. In the words of the Report,

While income from capital explains some of the extra money spent by parties the reminder must be seen as donations which may not be required to be disclosed under current legislation. ${ }^{190}$

The Committee concluded that as financial disclosure was an 'important adjunct to democracy', and in view of the 'alarming lack of information of sources of election funding', it was necessary to take 'brave steps' - namely to give the Commission power to conduct spot audits of political parties, and then to make public records of such. ${ }^{191}$

\section{(iii) Third Parties}

The other significant issue which the Committee considered was the increasing use of third parties to channel funds into the political process, either on their own behalf or on the behalf of an existing party. Here the Committee predicted correctly the increased role that third parties would play in future campaigns ${ }^{192}$

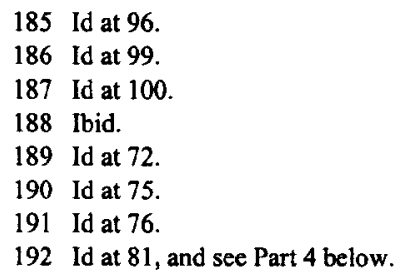


and therefore recommended that the Commission publish a full list of these bodies, ${ }^{193}$ that they be subject to the same disclosure requirements as other political participants, ${ }^{194}$ and that any third parties known to have a financial relationship with political parties be subject to spot audits. ${ }^{195}$ Importantly, the Committee also recommended that third parties be required to disclose in relation to any election and not just the election bounded by the current disclosure period. ${ }^{196}$ The reason for this was to avoid the apparently common practice of third parties of donating outside the disclosure period for the instant election and thereby avoiding the disclosure requirement. ${ }^{197}$

Despite the view of the committee that a ban on advertising was not warranted, when the legislation was presented in the parliament, a ban is exactly what it contained, along with some free time and disclosure provisions. The Political Broadcasts and Political Disclosures Act 1991 (Cth) introduced a new Part IIID into the Broadcasting Act 1942 (Cth). The object of the amendment was to prohibit the broadcasting, on radio or television, of political advertisements during an election period. ${ }^{198}$ The legislation therefore purported to ban broadcasting of advertisements containing political matter ${ }^{199}$ or prescribed material ${ }^{200}$ and broadcasting of any matter (subject to limited exceptions discussed below) by all governments (Commonwealth, ${ }^{201}$ state, ${ }^{202}$ or territory ${ }^{203}$ ) and government authorities in Australia's federal system, during an election period. An election period included federal elections and referenda, and territory, ${ }^{204}$ state, ${ }^{205}$ and local government elections.

Broadcasting of some otherwise prohibited material was permitted under three exceptions. First, broadcasting was permitted of news or current affairs, and comment ${ }^{206}$ or talkback, ${ }^{207}$ as well as some advertisements for public health, ${ }^{208}$ charities, ${ }^{209}$ and the visually handicapped. ${ }^{210}$ Second, a federal government statutory authority, the Australian Broadcasting Tribunal, was vested with the power to allocate free time to some participants in the political process. Ninety per

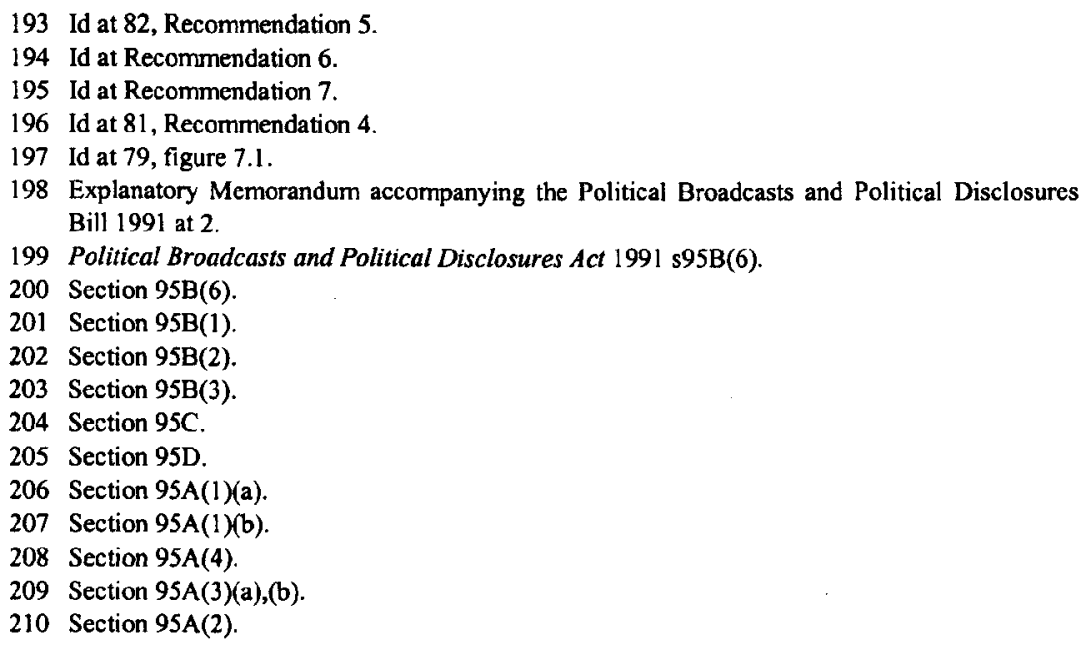


cent of the free time allocation was to be divided amongst parties who were already represented in the parliament and were contesting the election, with time given in proportion to the number of first preferences obtained at the last election. 211 The remaining 10 per cent of free time was to be divided amongst two groups. Free time would be allocated to Senators who were former members of a party that had a free-time allocation. ${ }^{212}$ The Tribunal then had discretion to allocate the remaining percentage to independent candidates and political parties. ${ }^{213}$ The third exception to the total prohibition on advertising was that political parties already represented in the parliament might broadcast a policy launch. ${ }^{214}$

The insertion of Part IIID was challenged by licensees of broadcasting stations and by the State of New South Wales. The grounds of the challenge included, inter alia, contravention of an implied constitutional guarantee of freedom of communication in relation to the electoral process; interference with the functioning and integrity of the states; imposition of a burden or a disability amounting to discrimination against the activities of the states: contravention of the guarantee of freedom of interstate intercourse contained in section 92 of the Constitution; and contravention of section 51(31) of the Constitution concerning acquisition of property on otherwise than just terms.

In an historic decision the High Court struck down the ad-ban regime, and, in the process, identified that the Constitution contained an implied right to freedom of communication in relation to political matters derived from the concept of representative democracy. ${ }^{215}$ A majority ${ }^{216}$ of the court said that sections of the Constitution, including sections 7 and 24, encapsulated an essential feature of the Australian constitutional system, namely representative democracy. The judges differed as to the consequences of this finding, although all agreed that, at the very least, representative democracy required that representatives be directly chosen by the people. Direct choice included the right to communicate and receive information necessary for the making of that choice. However, whereas six of the seven judges ${ }^{217}$ (including one from the minority, Brennan J) said that the Constitution itself must therefore protect the right to freedom of speech in relation to political matters involved in the making of that choice, one judge, Dawson J, said in a system of parliamentary supremacy individual rights were protected by the parliament, not by judges reviewing the Constitution. ${ }^{218}$ The remaining minority judge, Brennan J, upheld the legislation as a reasonable regulation of the political process, even though it did trench upon the implied freedom. 219

\footnotetext{
211 Section $95 \mathrm{H}(1)-(3)$.

212 Section $95 \mathrm{~L}(1)$.

213 Section 95M(1), (2).

214 Section 95S.

215 Australian Capital Television Pty Ltd v Commonwealth (1992) 177 CLR 106.

216 Ibid (Mason CJ, Gaudron, McHugh, Deane \& Toohey JJ; Brennan \& Dawson JJ dissenting).

217 Id at 140 (Mason CJ), 149 (Brennan J), 168 (Deane \& Toohey JJ), 215-216 (Gaudron J), 227 (McHugh J).

218 Id at 186 (Dawson J).

219 Id at 169 (Brennan J).
} 
The implied freedom of communication could only be restricted where there was a compelling justification for so doing, and where the restrictive measure was proportionate to the object being addressed. The majority and one member of the minority, Brennan $\mathrm{J}$, said that there was a compelling justification for the legislation, being the preservation of the integrity of the political process by limiting opportunities for corruption caused by the high cost of political advertising. ${ }^{220}$ Nevertheless the prohibition contained in the legislation was prima facie an interference with the implied freedom. In the view of the majority, the measures adopted to achieve that legitimate purpose were excessive and discriminatory, and thus failed the test of proportionality. The reasons for this were varied: the Act restricted not just political advertising, but all political communication during the relevant period; ${ }^{221}$ the provisions discriminated in favour of existing political candidates and excluded political communications by non-endorsed individuals; ${ }^{222}$ the mode of communication being restricted (namely television especially, as the most effective mode available); ${ }^{223}$ and the fact that other measures, such as spending limits and disclosure requirements, could have achieved the same legislative purpose. ${ }^{224}$ The legislation did not pass the twin tests of reasonableness and proportionality, and hence contravened the implied freedom.

Other grounds argued by the plaintiffs were generally not considered in great depth by the court. In relation to interference with the functioning of the states, McHugh J said that the legislation did interfere with their functioning, ${ }^{225}$ two judges discussed whether the scheme constituted an acquisition of property by the Commonwealth without just compensation, and all said that the rights involved were not proprietary in nature ${ }^{226}$ and Dawson $J$ said there was no contravention of section 92 , and that the legislation did not discriminate against the states. ${ }^{227}$

One of the legacies of the High Court's striking down of the constitutionality of the Bill was the loss of the changes to the disclosure regime. These were taken up again the following year.

\section{1992 Amendments - The Introduction of Annual Returns}

The Commonwealth Electoral Amendment Act 1992 was introduced with a major change to the disclosure regime, which had failed to survive the constitutional challenge to the broadcast ban. ${ }^{228}$ Instead of requiring political parties and their state branches to submit election returns for donations and expenditure, they were

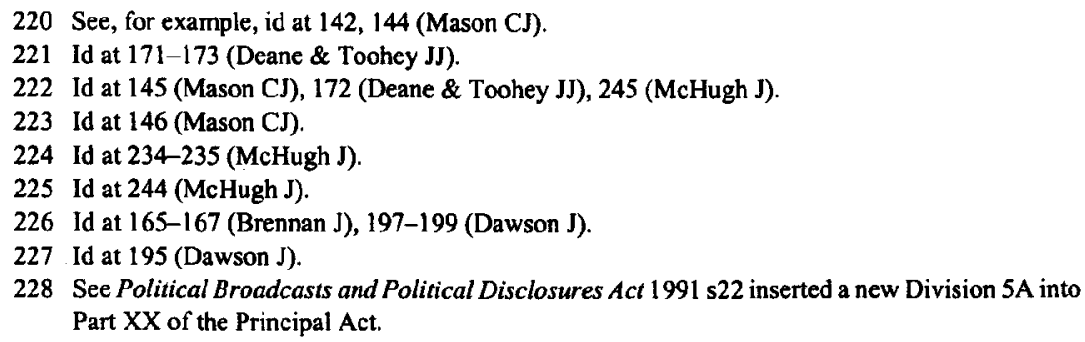

228 See Political Broadcasts and Political Disclosures Act 1991 s22 inserted a new Division 5A into Part XX of the Principal Act. 
now required to produce an annual return disclosing all receipts, payments and debts. ${ }^{229}$ The return had to list all transactions (payments, receipts or debts) of $\$ 1500$ or more, and provide certain particulars. The amount of each transaction, plus each amount making up the sum, and its date of receipt had to be disclosed. In addition, the names and addresses of officers of the particular body involved in the transaction were also to be provided. So, for unincorporated associations disclosure extended to the name of the association, and the names and addresses of its executive committee; for trust funds and foundations, it extended to the names and addresses of the trustees and the title of the fund; and for any other cases, the name and address of the person or the organisation. This latter category would presumably include registered industrial organisations. Candidates were still required only to submit election expenditure and donation returns.

\section{J. 1994 Recommendations and 1995 Act}

One of the unfortunate legacies of the latter amendments was that they placed a new administrative burden upon political parties who were now required to list, in minute detail, every financial transaction they undertook. Partly in response to pressure from political parties, the Joint Standing Committee on Electoral Matters (JSCEM) produced an interim report in June 1994 entitled Financial Reporting by Political Parties, the recommendations of which it hoped would be introduced during July $1994 .{ }^{230}$ The Committee was convinced that there was an 'urgent need to simplify the reporting requirements' and to 'alleviate the worst of the bureaucratic requirements associated with annual returns' without sacrificing the accountability goals of the legislation. ${ }^{231}$ To this end it recommended that only total amounts of expenditure be listed by political parties in their annual returns, instead of individual transactions. ${ }^{232}$

Other important recommendations made in the 1994 Report included: the setting of a threshold of $\$ 500$, below which individual amounts received or paid by political parties did not have to be reported (although the total of $\$ 1500$ from one entity remained); ${ }^{233}$ the abolition of the requirement of donors' returns; ${ }^{234}$ amendment of the Act requiring disclosure of income received by a political party from a trust fund or similar account; ${ }^{235}$ and the introduction of the same amount of public funding for Senate seats as for the House of Representatives. ${ }^{236}$ All recommendations except the abolition of donors' returns were accepted and incorporated into legislation.

229 Commonwealth Electoral Amendment Act 1992 s12 amending sections 314AB, 314AC, 314AD, and 314AE of the Principal Act.

230 Australia, Joint Standing Committee on Electoral Reform, Financial Reporting by Political Parties: interim report (Canberra: AGPS, 1994) at 3.

231 Id at 2-3.

232 Id at 4 .

233 Id at 5 .

234 Id at 6.

235 Id at 8

236 Id at 9 
In 1994, a Bill was introduced into the House implementing the recommendations. Four main changes were introduced. The reporting requirements were simplified so that only totals of amounts received had to be listed in the annual return, not every sum that made up the amount. ${ }^{237}$ This removed the 'unnecessarily onerous reporting requirements for registered political parties'. ${ }^{238}$ Moreover, parties were only required to count individual transactions of $\$ 500$ or more for determining whether an individual had reached the $\$ 1500$ threshold for detailed disclosure. Second, annual reporting by donors was introduced ${ }^{239}$ so as to facilitate cross-checking ${ }^{240}$ with political party returns which were now done on an annual basis. ${ }^{24 l}$ Third, public funding was increased and equalised between the Senate and the House of Representatives. ${ }^{242}$ The increase was justified on the basis that the costs of campaigning had increased ${ }^{243}$ and that since disclosure had been introduced donors were more reluctant to contribute. ${ }^{244}$ Moreover the legislative scheme for funding was altered to the effect that participants were entitled to receive funding automatically regardless of how much or whether they spent on the election campaign. This had the twin advantages, of speeding up the process for the AEC, and reducing the administrative burden to the participants. ${ }^{245}$ Political parties were, once again, required to furnish an electoral expenditure return, ${ }^{246}$ and the definition of electoral expenditure was amended to include direct mail. ${ }^{247}$

Finally, the disclosure provisions were extended to include entities associated with political parties ('associated entities' under the Act), ${ }^{248}$ and donations to such entities were also brought within the scope of the Act. ${ }^{249}$ For the first time, entities closely associated with registered political parties such as companies, trust funds and foundations were brought within the disclosure requirements. Additionally, associated entities were obliged to disclose capital deposits used to earn income that was subsequently passed on to parties. In introducing the Bill to the Parliament, the Minister described this as the closure of a 'loophole' which was being 'flouted' by one party which had just received $\$ 7.2$ million 'laundered'

237 Commonwealth Electoral Amendment Act $1995 \mathrm{~s} 3$, amending $\mathrm{s} 314 \mathrm{AC}(3)$ of the Principal Act.

238 Australia, House of Representatives, Parliamentary Debates (Hansard), 9 March 1995 at 1949.

239 Commonwealth Electoral Amendment Act 1995, inserting new s305B into the Principal Act.

240 Explanatory Memorandum accompanying the Cormmonwealth Electoral Amendment Bill (No. 2) 1994 at $₫ 22,6$.

241 Commonwealth Electoral Amendment Act 1995, inserting new s314AEA into the Principal Act.

242 Commonwealth Electoral Amendment Act 1995, amending s294(1), (2) and (3) of the Principal Act. The actual rate of funding, adjusted for CPI, was 157.594 cents per vote: Australian Electoral Commission, Funding and Disclosure Report Election 96 (1997) at 3.

243 Above $\mathrm{n} 240$ at 2

244 Australia, House of Representatives, Parliamentary Debate (Hansard), 9 March 1995 at 1950.

245 Australian Electoral Commission, above $\mathrm{n} 242$ at 1

246 Commonwealth Electoral Amendment Act 1995, amending s308(1)(f) of the Principal Act.

247 Commonwealth Electoral Amendment Act 1995, amending Division 5A of Part XX (heading) of the Principal Act.

248 Id at inserting new definitions into s287(1) of the Principal Act; s19 inserting new s314AE(1) into the Principal Act; 12.

249 Id at amending subs305(1) of the Principal Act. 
through a trust, which was not disclosed to the AEC. ${ }^{250}$ The Opposition, while not opposing the Bill, did indicate that they were opposed to the 'retrospective' element of the Bill contained in the provisions relating to annual returns of trust funds. In requiring details on sources of capital that may have been contributed when there was no question of disclosure, the Bill, according to the opposition parties, was retrospective in operation. ${ }^{251}$

\section{The Past Five Years - Associated Entities and Disclosure}

\section{A. The 1996 Federal Election}

In reporting on the 1996 election the Electoral Commission made a number of recommendations for reform of the legislation. Some were largely mechanical. These included the payment of election funding in the registered name of parties or branches rather than individual party agents; ${ }^{252}$ the increase of the threshold for disclosure of donations to candidates from $\$ 200$ to $\$ 1000 ; ;^{253}$ the increase of the threshold for disclosure of electoral expenditure by third parties from $\$ 200$ to $\$ 1000 ;^{254}$ and correlating the thresholds for anonymous donations with the disclosure threshold. ${ }^{255}$

Other matters went to the heart of the regulation of transparency. For example, one issue identified by the Commission was that since the introduction of the annual return requirement for parties, there was no longer a separate listing for donations within the receipts listing by parties. Apart from the confusion this created (with, for example, one journalist reporting maturity of an investment as a bank donation) it complicated the Commission's task of identifying donors who should be required to lodge returns. ${ }^{256}$ Accuracy is obviously essential, and here the Commission recommended that political party annual returns be accompanied by a report from an accredited auditor. 257

Due to the uncertainty of the definition of 'associated entity', the Commission sought broader powers of investigation and subpoena which would allow it to serve a notice upon an organisation to inspect relevant documentation to ascertain whether it fell within the definition. ${ }^{258}$ The Commission warned of the need to amend the legislation to more tightly define what was an associated entity. ${ }^{259}$

250 Francis Walker, Australia, House of Representatives, Parliamentary Debates (Hansard), 9 March 1995 at 1950.

251 Id at 1952.

252 For example, based on figures in the AEC 1996 Report an individual agent of the NSW Australian Labor Party would have received a cheque in the sum of $\$ 4451179.49$, and the Liberal counterpart would have received a payment for $\$ 3537309.22$ : Australian Electoral Commission, Funding and Disclosure Report Following the Federal Election held on 2 March 1996 at 3.

253 Id at 28 (Recommendation 3).

254 lbid (Recommendation 4).

255 lbid (Recommendation 8 ).

256 Id at 13 .

257 Ibid.

258 Id at 17.

259 Id at 16 . 
In addition, the Report identified other problems without making recommendations. These included the fact that broadcaster and publisher returns disclosing electoral expenditure were rarely inspected by the public despite the considerable administrative burden they placed upon the media. However the Commission cautioned against their abolition since they may be the only source of this information. 260

In relation to compliance audits of parties, associated entities' annual returns, and third parties' election returns, the Commission indicated that it was moving to a 'risk-based approach'261 which would be based upon identified risk factors and levels of financial activity. They commented that in general the standard of compliance was variable, and that some significant errors and omissions had been found. ${ }^{262}$ These were in part the result of a lack of preparation and planning for disclosure and the inadequacy of accounting systems. ${ }^{263}$ The Commission commented that the situation could be improved by the incorporation of parties and their subjection to other financial regulation. 'Apart from enhancing the disclosure system, this would have the added advantage of protecting party finances.' 264

Furthermore, the Commission indicated that it may be time to consider the creation of offences without the requirement of knowledge. ${ }^{265}$

\section{B. Recommendations of the Joint Standing Committee on Electoral Matters' Report of the Inquiry into the Conduct of the 1996 Federal Election}

One of the continuing controversies in the scheme concerns election expenditure returns. In the 1983 Act this was a requirement for all participants, and for third parties. The requirement was subsequently removed for the 1993 election $^{266}$ and then reinstated in $1995 .{ }^{267}$

The merry-go-round on election expenditure returns continued in the Report of the Inquiry into the Conduct of the 1996 Federal Election by the Joint Standing Committee on Election Matters. The Committee noted the Liberal Party view that annual and election returns contained a level of unnecessary duplication and the ALP view that annual audited accounts could replace both, and the AEC's acceptance of the abolition of the electoral return. They recommended that the electoral return be abolished and that registered parties be allowed to lodge audited accounts annually in place of annual returns, as long as the detail and format conformed with the requirements of the Commission and of the Act. ${ }^{268}$

\footnotetext{
260 Id at 11 .

261 Id at 19.

262 Id at 20.

263 Ibid.

264 Ibid.

265 Ibid.

266 Commonwealth Electoral Amendment Act 1992 (Cth) s 12.

267 Commonwealth Electoral Amendment Act 1995 (Cth) ss5 and 6.

268 Australia, Joint Standing Committee on Electoral Matters, Report of the Inquiry into All Aspects of the Conduct of the 1996 Federal Election and Matters Related Thereto (Canberra: AGPS, $1997)$ at 102 (Recommendation 60).
} 
Other recommendations were made by the Joint Standing Committee. The Committee considered the view proposed by the Liberals that the total threshold for reporting donations be increased to from $\$ 1500$ to a total of $\$ 10000$, and that individual amounts received not be included unless they were over $\$ 1500$. The purported point of these changes was to relieve the administrative burden of record-keeping for volunteers in local branches, ${ }^{269}$ although in submission the AEC argued that an increase from $\$ 500$ to $\$ 1500$ would not achieve this. In contrast the Committee argued that donors were already able to make a donation of $\$ 1499$ to each state and national branch, and that to raise the total threshold to $\$ 10000$ would allow up to nine donations of just under that amount, a total about just under $\$ 90000$ which could remain hidden from scrutiny. ${ }^{270}$

The Committee was sceptical of this view of widespread hidden money flowing in to the political system. They said that thresholds should 'more accurately reflect current financial values', ${ }^{271}$ indicating perhaps that people can afford to donate more these days to political parties than the legislation's figures suggest. They continued, perhaps a little optimistically, that it was 'most unlikely' that donors would go to such extraordinary lengths to conceal their allegiances. ${ }^{272}$ Even $\$ 90000$ spread over nine branches, state and federal, was 'hardly likely to engender corruption' ${ }^{273}$ Echoing the wisdom of Solomon, they decided to compromise and proposed to increase the total threshold to $\$ 5000$, and the threshold for counting individual sums received from a person be increased from $\$ 500$ to $\$ 1500$.

Donor disclosure was another issue canvassed by the Committee. The Liberal Party argued for abolition of donor disclosure. This was strongly rejected by the AEC on two grounds. They pointed out that it would effectively make disclosure of donations a purely voluntary arrangement. As long as donors kept their donations in lots below $\$ 500$, the threshold above which political parties were not obliged to report them, contributions could go completely undetected if there were no additional donor disclosure obligation. Moreover, as annual party returns do not distinguish between donations and other receipts, there was no way to identify which contributions to parties of $\$ 1500$ were donations and which were not. The Committee recommended the maintenance of donor returns but steeply increased the threshold for disclosure from $\$ 1500$ to $\$ 10000$ because the current level was 'unreasonably low and must discourage many potential donors'. 274

On tax deductibility the Committee recommended the increase of level of donation which would qualify for a deduction under taxation legislation from $\$ 100$ to $\$ 1500$ in order to 'encourage small to medium donations, thereby increasing the number of Australians involved in the democratic process and increasing the parties' reliance on a smaller number of large donations'. 275

269 Id at 100.

270 Id at $100,101$.

271 lbid.

272 Ibid.

273 Ibid.

274 Id at 102 (Recommendations 58 \& 59). 
In relation to compliance, it is interesting that the Committee rejected the submissions of the major parties to the effect that 'substantial compliance' was sufficient in view of the large number of volunteer workers involved in the collection and submission of material for the purposes of the Act. The Committee pointed out that only offences made with knowledge were subject to penalties so that there was no need for 'relaxed penalty provisions'. 276

In relation to public funding, the Committee recommended changing the current system from a set amount for each vote to an amount based upon its share of the primary vote taken as a proportion of a total pool of public funds, which would be set by the total enrolment at the close of rolls. ${ }^{277}$

Finally, the Report noted the concern of the major parties with the new requirements for 'associated entities' and suggested that government 'review' their operation. 278

\section{Electoral and Referendum Amendment Bill 1997}

In 1997 some of the changes recommended in the Joint Standing Committee Report were adopted. The Electoral and Referendum Amendment Bill 1997 (Cth) abolished the requirement that registered political parties lodge electoral expenditure returns, and it provided that parties lodge annual returns of expenditure in the approved form or lodge audited financial statements in a form which meets the legislation's requirements and is approved by the Electoral Commission. 279

More contentious was the question of associated entities. In the second reading debate on the Bill, Opposition member Mr Bob McMullan claimed that the government party was exploiting a loophole in the legislation by 'sidestepping the disclosure provisions'. ${ }^{280} \mathrm{He}$ identified a number of issues. The first was the making of donations to a foundation which then gave the money to the political party, thus avoiding the disclosure requirements of the Act because foundations were not within the disclosure provisions. ${ }^{281}$ This loophole had been addressed by the extension of the disclosure requirements to associated entities, but problems of definition still remained. The second issue therefore was the inability of the Commission to investigate effectively whether a particular body was an associated entity for the purposes of the Act. If the body in question said that it was not, or

275 Id at 104 (Recommendation 61).

276 Id at 104.

277 Id at 105 (Recommendation 63).

278 Id at 105.

279 Explanatory Memorandum accompanying the Electoral and Referendum Amendment Bill 1997 (Cth), Item 141, 142-144.

280 Australia, House of Representatives, Parliamentary Debates (Hansard), 23 March 1998 at 1346.

$281 \mathrm{Mr}$ McMullan referred to a situation prior to the 1995 amendments when the Free Enterprise Foundation had reportedly donated a large sum of money to the Liberal Party without disclosing the original sources of the donations: Australia, House of Representatives, Parliamentary Debates (Hansard), 23 March 1998 at 1347. 
simply refused to cooperate, ${ }^{282}$ the Commission was unable to do anything more, at least until after a regular compliance audit of the party which might take up to two years after the donations were made. The third problem was the provision of loans that might be unsecured, or provided at non-commercial rates. ${ }^{283}$

\section{The Ongoing Issue of 'Associated Entities'}

The issue of associated entities was first highlighted in 1994, when the then Labor government noted that large contributions were being made to the Liberal Party from an organisation called The Free Enterprise Foundation. ${ }^{284}$ These contributions were not transparent because foundations such as this were not subject to the disclosure provisions. Hence when a Liberal Party disclosure was made to the Commission it stated simply that a contribution was made by the named foundation but no further details gave the original source/s of the donations.

In 1992 changes had been introduced to the Act to bring within the disclosure provisions entities which were associated with political parties. ${ }^{285}$ However problems with the legislation remained, the main one in this respect being that the Commission lacked the investigatory powers necessary to determine whether or not an organisation fell within the definition of associated entity. The Commission could question the organisation and request information from them relating to their status, but if the organisation refused, the Commission felt it had no lawful way to pursue their investigation. In their Funding and Disclosure Report following the 1996 federal election, the Commission highlighted this problem saying that such a situation 'could give the appearance of disclosure only by consent and has the potential to undermine public confidence in the disclosure system'. ${ }^{286}$ As a result the Commission recommended that they 'be empowered to serve a notice upon the officers of an organisation for the purpose of ascertaining whether that organisation has an obligation to disclose as an associated entity'.287

The matter was brought up repeatedly in the Parliament during the period March to July 1998.

282 According to Mr McMullan, the Greenfields Foundation responded to a request from the AEC as to their status as an associated entity by claiming that they did not meet the definition and therefore were not required to provide further information: Australia, House of Representatives, Parliamentary Debates (Hansard), 23 March 1998 at 1348.

$283 \mathrm{Mr}$ McMullan speculated that when, in 1996-7, the Liberal Party reduced its debt to the National Australia Bank from $\$ 6762763$ to $\$ 158305$ and simultaneously was lent $\$ 4650000$ by the Greenfields Foundation that it was the beneficiary of a loan from the latter, a loan which may have been provided at less than commercial rates: ibid. The claim that any loan had been made at less than commercial rates was denied by the government spokesperson, John Fahey: Australia, House of Representatives, Parliamentary Debates (Hansard), 24 March 1998 at 1424.

284 Australia, House of Representatives, Parliamentary Debates (Hansard), 21 September 1994 at $1268,1274$.

285 Commonwealth Electoral Amendment Act 1992 (Cth).

286 Australian Electoral Commission, above n242 at 17.

287 Ibid (Recommendation 10). In the same recommendation, the AEC also suggested that such an organisation be given the right to appeal against such a notice. 
For example in Senate debates about appropriation in March, the Leader of the Opposition in the Senate, Senator Faulkner, accused the Liberal Party of 'deliberately trying to breach the spirit of the Electoral Act' and of trying to 'side step .... any form of public scrutiny of what is a huge sum of money from yet unknown Liberal Party donors'. 288

Specifically the debate raised a number of unresolved issues related to associated entities: unenforced loans; identification of associated entities; anonymous donation-making; and concessional loan arrangements. First, Senator Faulkner recounted the history of a loan of $\$ 4$ million made by the Greenfields Foundation to the Liberal Party in 1996-7, implying that the loan was to repay a bank debt which the party owed to the National Australia Bank. Second, he referred to what he called 'an uncanny number of similarities' ${ }^{289}$ between the Free Enterprise Foundation, which had been subject to the disclosure provisions, and the Greenfields Foundation, which had not. These similarities related to identification of trustees, postal address, and accounting support between the two foundations. Third, questions were raised regarding the methods of security for the funding, payment, and interest rates for the loan. Fourth, Senator Faulkner noted that although donations over $\$ 1500$ must be disclosed, loans need not, although he conceded that a loan 'of itself' was 'not a problem' 290 The real problem was in relation to the inability of the Commission to identify the Greenfields Foundation as an associated entity for the purposes of the Act, and thus the ability of the Foundation to 'collect substantial donations from sources which remain anonymous for the purposes of funding disclosure'. ${ }^{291}$ Despite requests from the Commission, the Foundation was not under any obligation to provide information and the Commission had 'no authority .... to go behind a separation foundation on the basis of any suspicion [it] might have'.292 Other than a regular compliance audit of the Liberal Party, which might take place every 2 years, there was no other way for the Commission to investigate.

The matter was taken up again on 10 March 1998 with a resolution by Senator Faulkner to take note of the 1996 Australian Electoral Commission Report. The Resolution drew attention to three problems: definitional uncertainty; lack of investigatory power; and the resultant undermining of public confidence in the disclosure system. ${ }^{293}$ A month later, a further resolution was moved by Senator Faulkner noting that, in some cases, the Commission was unable to determine whether an organisation should disclose and that there was nothing to prevent an organisation from claiming it did not meet the definition. Senator Faulkner called on the appropriate Minister to amend the Act to empower the Commission to investigate whether an organisation had an obligation to disclose as an associated entity. 294

288 Australia, Senate, Parliamentary Debates (Hansard), 3 March 1998 at 200.

289 Ibid.

290 Ibid.

291 Ibid. See also $\mathrm{n} 283$ above.

292 Australian Electoral Commission, above $\mathbf{n} 242$ at 17.

293 Australia, Senate, Parliamentary Debates (Hansard), 10 March 1998 at 735. 
In debate upon the Electoral and Referendum Amendment Bill 1997 (Cth), the Opposition foreshadowed that, whilst it supported the Bill in principle, it would move a number of amendments aimed at addressing this problem. It proposed to tighten the definition of associated entity to cover entities that operated wholly or to a significant extent for the benefit of one of more registered political party. ${ }^{295}$ The current definition included entities wholly or mainly for a party's benefit. The object of the change was, presumably, to catch organisations which may have other purposes which took them outside the ambit of the disclosure requirements, but which nevertheless operated to benefit political parties. The statement by a trustee of the Greenfields Foundation that it was a charitable foundation may have been what the amendment was addressing.

The second amendment would have altered the disclosure period so that if a loan was subsequently unenforced, converting it into a gift, the donor would nevertheless be obliged to disclose even if the gift was, as a consequence, outside the same disclosure period as the original donations. ${ }^{296}$ Third, the Opposition foreshadowed that it would seek to amend the Act so that only financial institutions could make loans to political parties, unless certain disclosure provisions were met, detailing the terms and conditions of the loan. ${ }^{297}$

The matter again came to a head when two other important changes were introduced into the Parliament in 1998 in the form of changes to taxation legislation. The first of these was relatively uncontroversial and involved including within the definition of tax deductibility those deductions that were made to independent candidates, as well as those made to political party members. Bipartisan support for this measure was apparent. The second change sought to increase from $\$ 100$ to $\$ 1500$ the amount that was tax deductible, and to allow companies to claim donations as tax deductions. Labor members of the Committee had fought hard for the ceiling to be maintained at $\$ 1500$ rather than $\$ 10000$, as proposed by the Liberals. However, when the Bill came to the House of Representatives it was still objected to upon other grounds.

Labor Member, Mr Bob McMullan, criticised the Bill for two reasons. First, the increase in tax deductibility levels would costs taxpayers some $\$ 45$ million over the next three years. ${ }^{298}$ Second, and more importantly, it failed to address what Mr McMullan called the " "Greenfields loophole" through which donations are made to the Liberal Party without any disclosure' ${ }^{, 29}$ In debate on the same Bill another Labor member, Mr Martin Ferguson, made the claim that the three largest donors to the Coalition Government were associated entities. ${ }^{300}$

On 25 June 1998, the Special Minister of State, Senator Minchin, moved an amendment to the Electoral and Referendum Amendment Bill 1998 (Cth) which

294 Australia, Senate, Parliamentary Debates (Hansard), 7 April 1998 at 2183.

295 Australia, Senate, Parliamentary Debates (Hansard), 28 May 1998 at 3357.

296 Ibid.

297 Ibid.

298 Australia, House of Representatives, Parliamentary Debates (Hansard), 3 June 1998 at 4664.

299 Ibid.

300 rbid. 
would empower the Commission to serve a notice upon an officer of an organisation suspected of being an associated entity to produce documents to enable that assessment to be made. ${ }^{301}$

The foreshadowed opposition amendments were introduced into the Senate on the same day, ${ }^{302}$ and supported by the Greens Senator on the basis that the device of making 'loans' to political parties where there is no intention to call in those loans was contrary to the intention of the legislation and was a 'potential device for hiding donations going to political parties. ${ }^{303}$ The Government reiterated its support for transparency and disclosure ${ }^{304}$ but rejected the amendments because the phrase 'significant extent' was an 'unworkable' definition, and changes to the disclosure period would have a retrospective effect. ${ }^{305}$ The opposition amendments were rejected. ${ }^{306}$ On July 1 the amendments framed by the Government, including increasing the power of the Commission to serve notices on organisations in order to ascertain whether they were associated entities, were returned to the House of Representatives where they were agreed to ${ }^{307}$ and the Bill finally passed as the Electoral and Referendum Amendment Act 1998 on the $17^{\text {th }}$ of July 1998. On the $9^{\text {th }}$ of February 1999, the AEC announced to the Senate Estimates Committee that it had served a 'please explain' notice upon the Greenfields Foundation on 15 January of that year. ${ }^{308}$

However, the issue still hadn't ended, with debate on the Taxation Laws Amendment Bill (No. 8) 1999 (Cth) focusing very much on the Greenfields issues. The area which seemed to have been causing so much controversy was the issue of tax deductibility for donations to prescribed private funds. The fear was that organisations, such as the Greenfields Foundation would be considered prescribed private funds for the purposes of the Act, thus enabling political donations via such organisations to be tax deductable as well as limiting public transparency. In view of this, the Senate moved amendments preventing certain private funds from being considered 'prescribed private funds' The amendments were returned having been rejected by the Government majority in the House of Representatives. The amendment in question restricted prescribed private funds from including any associated entities (within the meaning of the Commonwealth Electoral Act 1918 (Cth)) or any private fund which at any time makes, or had made, a gift, contribution or any other benefit to a political party registered under Part XI of the Commonwealth Electoral Act 1918 (Cth) ${ }^{309}$ The House objected to this on the grounds that the amendment was unnecessary as the Bill was already proposing to amend the Income Tax Assessment Act 1997 (Cth) such that a fund could 'only be

301 Australia, Senate, Parliamentary Debates (Hansard), 25 June 1998 at 4080.

302 Id at 4174 (Senator Faulkner).

303 Robert Brown, Australia, Senate, Parliamentary Debates (Hansard), 30 June 1998 at 4463.

304 Ibid (Senator Minchin).

305 Nicholas Minchin, Australia, Senate, Parliamentary Debates (Hansard), 25 June 1998 at 4178.

306 Australia, Senate, Parliamentary Debates (Hansard), 30 June 1998 at 4115.

307 Australia, House of Representatives, Parliamentary Debates (Hansard), I July 1998 at 3181

308 Media release, 'Howard Fails on Greenfields Debt Question', Senator John Faulkner, 10 February 1999.

309 Australia, Senate, Parliamentary Debates (Hansard), 13 April 2000 at 14111. 
a prescribed private fund if it is established solely for the purpose of providing money to a fund or institution listed under Subdivision 30-B of that Act'. As political parties are not being listed under that Subdivsion, any fund established for the purpose of supplying money to a political party would hence not be considered a private fund. Despite this, however, Senator Kemp, the Assistant Treasurer would still not give a commitment that the Greenfields Foundation would not be considered a prescribed private fund for the purposes of the Act. ${ }^{310}$

However, the amendments were defeated in the Senate, following a change of heart on the part of the Democrats in order to get the Bill passed. Hence the Taxation Laws Amendment Act (No. 2) 2000 (Cth) was assented to on the $31^{\text {st }}$ of May $2000 .^{311}$ However, the very fact that this Bill was returned to the House three times, and was passed with considerable criticism by the Democrats, ${ }^{312}$ indicates that the issue of associated entities and political donations is far from over. This is emphasised by the recent debate over a Senate motion proposed by Senator Faulkner supporting the AEC's concerns regarding the Greenfield's Foundation ${ }^{313}$ as expressed in the AEC's Funding and Disclosure Report of the 1998 Federal Election. ${ }^{314}$

\section{E. Electoral and Referendum Act (No. 1) 1999}

A further piece of legislation, the Electoral and Referendum Amendment Bill (No. 2) 1998 (Cth), adopted a number of recommendations made in the JSCEM Report into the 1996 Election. The relevant ones for our purposes concern donations. First, it provided that political parties are only required to disclose amounts of $\$ 5000$ or more, rather than the previous $\$ 1500$ received from a person or organisation in a financial year. ${ }^{315}$ Second, in calculating this sum the Bill increased from $\$ 500$ to $\$ 1500$ the threshold under which individual donations must be counted. ${ }^{316}$ Third, under the proposed amendments, donors to political parties would only be required to disclose by way of a return if they donated $\$ 10000$ rather than the current $\$ 1500 .^{317}$

The Senate's Finance and Public Administration Legislation Committee considered the Bill and heard submissions concerning it in June 1998.

In relation to donors' disclosure, Senator Minchin put forward the view that the requirement was unnecessary both because it duplicated disclosure by parties, and

310 John Faulkner, Australia, Senate, Parliamentary Debates (Hansard), 13 April 2000 at 14115.

311 Taxation Laws Amendment Act (No. 2) 2000 (Cth) No. 58, 2000.

312 Andrew Bartlett, Australia, Senate, Parliamentary Debates (Hansard), 13 April 2000 at 14117.

313 John Faulkner, Australia, Senate, Parliamentary Debates (Hansard), 22 June 2000 at 15504.

314 See Australian Electoral Commission, Funding and Disclosure Report Following the Federal Election held on 3 October 1998 (Canberra: AGPS, 2000) Part 5.

315 Proposed amendment to s314AC(1). Explanatory Memorandum accompanying the Electoral and Referendum Amendment Bill (No. 2) 1998 at Item 44s \& 45.

316 Id at proposed amendment to $3314 \mathrm{AC}(2)$.

317 Id at proposed amendment to $5305 \mathrm{~B}(1)$. 
on privacy grounds. ${ }^{318}$ In relation to the aggregation figure above which amounts must be noted, there was bipartisan support for increase from $\$ 500$ to $\$ 1500 .^{319}$

The more controversial issue was the total amount that should be disclosed by political parties. A number of objections were raised before the Committee. The first was that if the threshold were increased to $\$ 5000$ approximately $20-30$ per cent of donations would not remain on the public record. ${ }^{320}$ Second, it was claimed that it would exacerbate the problem of 'splitting', whereby donors spread their donations either with other members of their family or with a company with which they have an association and avoid the disclosure level altogether. ${ }^{321}$ For example, the proposed increase would enable a donor to contribute without disclosure approximately $\$ 45000$ per year, or $\$ 135000$ per three-year election cycle, by contributing up to the threshold in each state and territory and national branch of a political party ${ }^{322}$ (the practice of splitting and donating just below the disclosure threshold is quite common according to the Australian Electoral Commission). ${ }^{323}$ The increased level would prevent the Commission from identifying where this is occurring under the $\$ 5000$ limit. Third, it was felt the increase did not address the problem of large gifts being made through associated entities which creates the impression that politicians are being influenced by moneyed interests. In evidence, Professor Rolf Gerritsen stressed the reasons behind disclosure laws applying to associated entities. He posed the hypothetical case of a large media proprietor donating large amounts of money to the Greenfields Foundation which gives the money to the party which won the election, which subsequently 'donates property that belongs to Australians, that is digital television channels, to that same media proprietor' ${ }^{324}$ If the donation is disclosed then according to Professor Gerritsen 'the possibility does not arise of any imputation of corrupt influence of government' 325

The Finance and Public Administration Committee reported on the Bill in June $1998 .^{326}$ After referring to the evidence, which suggested that 20-30 per cent of donations would go undetected under the proposed amendments, and to splitting, the Committee recommended, without remark, that the Bill be agreed to without amendment. ${ }^{327}$ The Australian Labor Party and the Democrats submitted minority reports. The ALP report supported an increase in the threshold for amounts to count towards disclosure from $\$ 500$ to $\$ 1500$ but opposed both the new donor threshold, and the new total over which political parties had to disclose. The ALP

318 Above $n 13$ at 20.

319 Id at 21

320 This figure is an estimate based on records kept by Professor Rolf Gerritsen between 1993 and 1998 showing 6000 reportable donors, the average of which was approximately $\$ 4000:$ id at 20 .

321 Evidence of Mr B Edgman, Australian Electoral Commission, id at 23.

322 Id at 22.

323 Above $\mathrm{n} 16$ at 38 .

324 Above $n 12$ at 20.

325 Id at 21.

326 Australia, Senate, Finance and Public Administration Legislation Committee, Consideration of Legislation Referred to the Committee - Provisions of the Electoral and Referendum Amendment Bill (No.2) 1998 (Cth), June 1998: <http:/www.aph.gov.au/senate/committee/ fapa_ctte/electoral/index.html>.

327 Id at 7. 
Senators stated that these amendments were a continuation of a 15-year policy to weaken disclosure and referred to this as the Coalition parties' 'tacit approval of the Greenfields Foundation rort'. ${ }^{328}$ The Democrats minority report also opposed these proposals. ${ }^{329}$

Subsequently, the Electoral and Referendum Amendment Act (No. I) 1999 (Cth) was enacted after the Senate in committee produced a number of amendments which considerably altered the Bill from that which had originally entered the Senate. ${ }^{330}$ These amendments included the acceptance of those failed amendments proposed by the Opposition to the Electoral and Referendum Amendment Bill 1998 (Cth) regarding the definition of associated entities, ${ }^{331}$ and limiting the acceptance of loans from persons or entities other than a financial institution unless certain disclosure provisions were met, detailing the terms and conditions of the loan. ${ }^{332}$ The more controversial issues of raising the disclosure level for political parties from $\$ 1500$ per financial year to $\$ 5000$, and for donors from $\$ 1500$ pa to $\$ 10000$, were dropped, although not entirely forgotten.

Recently, the Joint Standing Committee Electoral Matter's Report of the Inquiry into the 1998 Federal Election and Matters Related Thereto, revived the issue. Recommendation 44 of the report suggests that the disclosable sum received from a person or organisation during a financial year be increased from $\$ 1500$ to $\$ 3000,{ }^{333}$ believing that it is illogical for the minimum disclosable sum of donations be the same as the minimum for individual amounts received'. ${ }^{334}$ However, a dissenting minority report stated that such a move 'will only diminish the transparency of the disclosure laws and allow further donations to parties and candidates to go undisclosed' ${ }^{335}$ In support of this they quoted the AEC's report of the 1998 election published this year which acknowledged the continuing problem of donation splitting, and asserted that 'the only practical deterrent to donation splitting is to maintain a low disclosure threshold'. 336

The Greenfields Foundation arose as an issue of concern in both the AEC and JSCEM Reports on the 1998 election. The Committee's report seemed to treat the issue as resolved following the passing of the Electoral and Referendum Act (No. 1) 1999 (Cth), but the AEC Report raised a number of continuing concerns following its investigation of the Greenfields Foundation. It made it quite clear that despite changes to the legislation 'a person, or in certain circumstance a corporation, who wished to avoid full and open disclosure could do so by a series

328 Id at 9.

329 Id at 10.

330 Electoral and Referendum Act (No. I) 1999 (Cth).

331 Section 15 of the Electoral and Referendum Act (No. 1) 1999 repealed the phrase 'operates wholly or mainly for the benefit of one or more registered political parties' and inserted the phrase 'operates wholly or to a significant extent for the benefit of one or more registered political parties'.

332 Electoral and Referendum Act (No. 1) 1999 (Cth) s 19, inserting new s306A into the principal Act.

333 Still considerably below the Liberal Party's proposed increase to $\$ 10000$.

334 Joint Standing Committee on Electoral Matters, Report of the Inquiry into the 1998 Federal Election and Matters Related Thereto (Canberra: AGPS, 2000) at 128.

335 Id at 158.

336 Above $n 313$ at $14(\$ 4.16)$. 
of transactions based on the Greenfields model' ${ }^{337}$ It also felt that the legislative change in the definition of associated entities had merely added 'yet further imprecision, ${ }^{338}$ to the situation ${ }^{339}$ which it feared 'ultimately may only be able to be resolved before the courts on a case by case basis'. ${ }^{340}$

\section{F. Taxation Laws Amendment (Political Donations) Bill 1999}

This Bill was first introduced to the House of Representatives on the $28^{\text {th }}$ of May 1998. It proposed to widen the range of political contributions and gifts eligible for a tax deduction to include gifts and contributions made to independent members and candidates of the Commonwealth, State, Northern Territory or ACT Parliaments and Assemblies and elections, political parties registered under State or Territory legislation, and increase the maximum deduction to $\$ 1500$ per year. ${ }^{341}$ According to the Explanatory Memorandum, these amendments are designed to 'increase the number of Australians (including companies) in the democratic process and reduce a political party's reliance on a small number of large donations'. ${ }^{342}$ It is also designed to 'provide an equivalence of treatment between contributions to political parties and gifts to independent candidates and members' 343 These statements were supported by the Committee's report into the 1996 election. $^{344}$

Prior to the 1998 Bill lapsing, ${ }^{345}$ the Bill was debated in the House of Representatives where it was strongly opposed by the Labor Party on grounds relating to the transparency of political donations ${ }^{346}$ and the cost to taxpayers (estimated at $\$ 45$ million over three years) ${ }^{347}$ - the same arguments as had been used against the same measures in the Electoral and Referendum Amendment Bill 1997. The argument was that it was not the smaller, individual donors who would be benefiting from this Bill, but the more wealthy donors and corporations. ${ }^{348}$

The issue of associated entities continued to rear its head. The Labor member for Melbourne, Mr Lindsay Tanner, asked the question as to whether associated

337 Id at $16(\$ 5.6)$.

338 Id at $12(\$ 4.7)$

339 According to the AEC, '[o]rganisations continue to ask whether they fall within the definition of associated entity. Some entities submit disclosure returns accompanied by a disclaimer that it is not to be interpreted as an acceptance of their legal responsibility to do so': id at 12 ( $\{4.6$ ).

340 Ibid ( 94.7$)$.

341 Similar moves were being made at the same time with regards to the tax deductibility of donations of property valued at over $\$ 5000$ to political parties in the Taxation Laws Amendment Bill (No. 8) 1999 (Cth). The original attempt to place the deduction at $\$ 1500$ failed and the limit was set in the Taxation Laws Amendment Act (No. 2) 2000 at $\$ 100$.

342 House of Representatives, Explanatory Memorandum accompanying the Taxation Laws Amendment (Political Donations) Bill 1999.

343 Ibid.

344 Above n268 at 104 .

345 As it did when the federal election was called on 31 August 1998.

346 See, for example, Robert McMullan, Australia, House of Representatives, Parliamentary Debates (Hansard), 3 June 1998 at $4664-4690$.

347 Explanatory Memorandum accompanying the Taxation Laws Amendment (Political Donations) Bill 1999 (Cth).

348 Deductibility for corporations is to be included under Schedule one of the Bill. 
entities, referring once again to the infamous Free Enterprise Foundation, would be treated in the same manner as political parties for the purposes of attracting political donations. ${ }^{349}$ According to the definition in the Commonwealth Electoral $A c t$, associated entities are 'controlled by one or more registered political parties; or operate wholly or mainly for the benefit of one or more political parties' 350 The question was not answered.

Another issue brought up once again within this debate, was the persistent fear of 'heading down the American road for funding'. ${ }^{351}$ Australian politicians fear the Australian political system becoming like the United States, in terms of financial requirements for candidates and politicians. Moreover there is a belief that 'the people who own the country ought to run it'. ${ }^{352}$ Such an argument has been brought up regularly over the years, within both Parliament and the political media, with frequent reference to the astronomical costs of running for the Senate, and the exclusivity of the political race in the United States.

Debate on the taxation Bill was adjourned in the Senate on the $30^{\text {th }}$ of August $1999^{353}$ and was to be taken up again in the following session of parliament. It will be interesting to see the impact upon the debate of the successful Opposition amendments to the Electoral and Referendum Act (No. 1) 1999 (Cth) and Taxation Laws Amendment Act (No. 2) 2000 (Cth) and it is probable that debate on the provisions regarding tax deductibility of donations it will continue to be heated.

\section{Conclusion - A Full Circle?}

Campaign finance regulation in Australia has undergone considerable re-vamping since the original 1902 legislation. Apart from spending limits, the key principles of regulation - equality, transparency, and accountability - have remained essentially the same, and even the methods have not so much changed as merely adapted to suit changing times. As noted above, the problem for regulators is that this area is always a case of 'catch-up politics'. ${ }^{354}$ As soon as one loophole is closed, another will open. Equally, as previously noted, what is important in this area is the perception that money can influence politics. Findings such as those in the 1998 opinion poll, showing that less than 10 per cent of Australians believed that their politicians held high standards of ethics and honesty ${ }^{355}$ are, perhaps, the greatest impetus to politicians whose very livelihood depends (theoretically) upon popular support and a certain level of belief in their credibility. Naturally, this concern is combined with a determined effort to see that 'the other side' has as

349 Australia, House of Representatives, Parliamentary Debates (Hansard), 26 August 1999 at 9182.

350 Commonwealth Electoral Act $1918 \mathrm{~s} 287(1)$, although this was subsequently amended by $\mathrm{s} 15$ of the Electoral and Referendum Act (No. I) 1999 (Cth).

351 Australia, House of Representatives, Parliamentary Debates (Hansard), 26 August 1999 at 9193-9194, 9202, 9247.

352 Id at 9183, Mr Andren (Calare), quoting US 'founding father' John Jay.

353 Two weeks prior to the passing of the Electoral and Referendum Act (No.1) 1999 (Cth).

354 Laurie Ferguson, Australia, House of Representatives, Parliamentary Debates (Hansard), 3 June 1998 at 4676.

355 Above $n 17$. 
little an advantage as possible, particularly in an area such as campaign finance that can have such an impact upon a party's future. However, it is that very impact which seems to be the focus of the next wave of regulations regarding campaign finance. The use of public funding appears to be coming increasingly under the spotlight following the last federal election with increased calls for it to be subject to tighter regulation.

The presence of the One Nation party in the 1998 federal election also had a controversial effect for reasons other than their policies on immigration and indigenous peoples. According to members of the current JSCEM, following the election, One Nation made a number of public comments indicating that the party viewed the election as a 'money gathering exercise through public funding'. ${ }^{356}$ The obvious concern this raises is that political parties are not utilising public funding for appropriate purposes. ${ }^{357}$ At the JSCEM inquiry into the 1998 Election Mr Gary Gray, National Secretary of the Australian Labor Party, made the point that:

Whereas political parties certainly gain freedom from the way in which current disbursement of public funding takes place, I believe that we should be prepared to take some limitations on that freedom in order to prevent profiteering out of federal elections .... Therefore our first recommendation is to consider a change to the act whereby we move back to a system of reimbursement for outlays made by political parties. ${ }^{358}$

This issue was raised in both the Joint Standing Committee on Electoral Matters' Report of the Inquiry into the 1998 Federal Election and Matters Related Thereto, ${ }^{359}$ and the Australian Electoral Commission's Funding and Disclosure Report of the 1998 Federal Election. ${ }^{360}$ Both concluded that 'the reimbursement scheme is not a guarantee that profits could not be made on election funding'. ${ }^{361}$

A more radical call in terms of public funding has been made by the Independent member for Calare, Mr Peter Andren, on a number of occasions. To some extent his solution, which involves the introduction of a cap on public funding, brings this article full circle. While not identical to the $1902 \mathrm{Act}$, which limited electoral expenses but did not envisage public funding, the Andren proposal is similar in that both approaches seek to restrict amounts spent in election campaigns. In a speech to Parliament against the Electoral and Referendum Amendment Bill (No. 2) 1998, Mr Andren stated:

The moral of the story is that millions in donations to political parties are a good investment considering the billions that can be ultimately saved through government favour .... The amount of money taxpayers fork out through public funding of elections should be enough on its own without our political parties

356 Joint Standing Committee on Electoral Matters, Official Committee Hansard, Conduct of the 1998 Federal Election and Matters Related Thereto, Canberra, Thursday 1 April 1999 at EM20.

357 See, for exampie, W Brown, 'Party funding and other touchy political issues', Courier Mail (5 February 1999) at 17.

358 Ibid.

359 Above $\mathrm{n} 334$ at 125.

360 Above n314 at 4 (\$2.7)

361 Above n334 at 126. 
having to resort to taking secret donations on top of that. I estimate a cap of $\$ 50000$ per candidate would be absolutely adequate for any campaign at federal level in this country. ${ }^{362}$

This may be a considerable increase from the original legislative provisions limiting expenses to $£ 100$ for candidates for the House of Representatives and $£ 250$ for the Senate ${ }^{363}$ but it is not a radically new idea. Similarly a desire to contain the cost of election campaigns, whether publicly funded or not, appeared in the JSCEM's Report of the Inquiry into the 1998 Federal Election and Matters Related Thereto where a number of submissions argued that restrictions should be placed upon the amount which could be spent on election campaigns in order to reduce the amount of public spending. ${ }^{364}$ Others called for the elimination of public funding to political parties for election campaigns altogether. ${ }^{365}$ Dr Carmen Lawrence, in turn, has suggested a ban on donations from corporations and other large organisations and a cap of $\$ 1500$ on individuals. ${ }^{366}$ In light of the release of figures showing a $\$ 31103228.82$ bill for taxpayers following the 1998 election, ${ }^{367}$ and combined with the proposed $\$ 45$ million bill if the Taxation Laws Amendment (Political Donations) Bill 1999 passes unamended, there are likely to be further questions raised about the efficacy of public funding in combination with the benefits handed out to further encourage individuals and corporations to donate to political parties. ${ }^{368}$

In short we have argued, first, that bar brief periods of inactivity, the overall trend has been one of increased regulation and an increasingly complex regulatory environment. Issues under regulation include: control on the conduct of political parties and private donors in terms of transparency and disclosure requirements; enhancement of the ability of private donors to contribute to the political process by way of tax incentives; use of public funding by political parties to maximize their financial position; capping public funding; contribution limits for individuals and for corporations. Underlying all these matters is the tension between increasing private participation in the public political activity of elections whilst at the same time funding elections from the public purse. Tighter regulation of public funding is likely to be a key question in the future, as is the relationship between public funding and private contribution. In respect of the latter in the past five years, legislation has extended to include regulation of entities associated with political parties and candidates, rather than the political participants themselves. But while the involvement of groups beyond the traditional political participants has been encouraged on the whole, the conflict between 'popular participation'

362 Australia, House of Representatives, Parliamentary Debates (Hansard), 2 December 1998 at 1178.

363 Commonwealth Electoral Act 1902 s 169.

364 Above n314 at 123 and Submissions ppS214 (GW Spence) and S632-S633 (E Lockett).

365 Id at 123 and submissions ppS592 (H\&M Whitton), S667 (M Goldstiver) and S1 844 (A Tuck)

366 Dr Carmen Lawrence, quoted in Michelle Grattan, 'Money and the Politics of Schmooze', The Sydney Morning Herald (25 August, 2000).

367 Media Release, '1998 Federal Election Funding Payments Announced', Australian Electoral Commission, 29 October 1998.

368 Moreover, Recommendation 6 of the AEC's Funding and Disclosure Report of the 1998 Federal Election has made it clear that the issue of 'associated entities' is not over yet. 
through monetary contribution and the fear of financial influence will no doubt be brought out again in the Senate discussions of the Taxation Laws Amendment (Political Donations) Bill 1999, and in debates following the release of the JSCEM and AEC reports into the 1998 elections. Indeed, Dr Carmen Lawrence, in an address to the Sydney Institute in August 2000 expressly addressed this issue ${ }^{369}$ noting that whilst public funding on elections was supposed to reduce the parties' alliance on private, corporate and union donations, 'all that has happened is a blowout in both public (doubled since 1993) and private funding as parties engage in an increasingly expensive bidding war at elections'. ${ }^{370}$

Second, we have suggested that, spending limits aside, despite the increased reach of the Australian regulatory system the same themes and concerns permeate the current framework as its historical predecessors. Far from being recent innovations, the requirements of the current system regarding disclosure and transparency, third party regulation, contribution limits and an emphasis on media regulation were all present in the early system. Moreover, although spending limits are not a part of the current regulatory framework, they were an accepted element of the Australian political and legal landscape for over 80 years before their abolition in 1980 .

Third, and finally, we have argued that in view of the historical precedent for campaign expenditure limits, and their compatibility with representative democracy as interpreted in the Australian constitutional context, the development of an implied right to freedom of political communication would be unlikely to operate as a barrier to the re-introduction of expenditure limits. This is most important in the context of the discussion of public financing taking place following the last federal election. The recommendations of the JSCEM inquiry into the 1998 federal election will no doubt spark increased debate into the use of public monies, and almost certainly re-introduce this issue into the political and legislative arena.

369 A complete transcript of the August 172000 speech on 'Renewing Democracy: Can Women Make a Difference' is available online at <http://www.carmenlawrence.com/says/papers/ sydneyinstitute.htm>.

370 Dr Carmen Lawrence, quoted in Grattan, above $n 366$. 
This text is taken from Traversing the Divide: Honouring Deborah Cass's Contributions to Public and International Law, edited by Kim Rubenstein, published 2021 by ANU Press, The Australian National University,

Canberra, Australia.

doi.org/10.22459/TD.2021.14 